\title{
Article \\ Modelling the Interactions of Soils, Climate, and Management for Grass Production in England and Wales
}

\author{
Michail L. Giannitsopoulos ${ }^{1, *(\mathbb{C})}$, Paul J. Burgess ${ }^{1}\left(\mathbb{D}\right.$, Goetz M. Richter ${ }^{2}{ }^{(}$, Matt J. Bell ${ }^{3}$, \\ Cairistiona F. E. Topp ${ }^{4}{ }^{\circledR}$, Julie Ingram ${ }^{5}$ and Taro Takahashi ${ }^{6,7}$ \\ 1 Soil and Agrifood Institute, Cranfield University, Cranfield, Bedfordshire MK43 0AL, UK; \\ p.burgess@cranfield.ac.uk \\ 2 Rothamsted Research, Sustainable Agriculture Sciences, Harpenden AL5 2JQ, UK; \\ goetz.richter@rothamsted.ac.uk \\ 3 Agriculture Department, Hartpury University, Gloucester GL19 3BE, UK; matt.bell@hartpury.ac.uk \\ 4 SRUC, Peter Wilson Building, West Mains Rd, Edinburgh EH9 3JG, UK; kairsty.topp@sruc.ac.uk \\ 5 Countryside \& Community Research Institute, University of Gloucestershire, Gloucestershire GL50 4AZ, UK; \\ jingram@glos.ac.uk \\ 6 Rothamsted Research, Sustainable Agriculture Sciences, North Wyke, Okehampton EX20 2SB, UK; \\ taro.takahashi@rothamsted.ac.uk \\ 7 Bristol Veterinary School, Cabot Institute for the Environment, University of Bristol, Langford House, \\ Langford, Somerset BS40 5DU, UK \\ * Correspondence: m.giannitsopoulos@cranfield.ac.uk
}

Citation: Giannitsopoulos, M.L.; Burgess, P.J.; Richter, G.M.; Bell, M.J.; Topp, C.F.E.; Ingram, J.; Takahashi, T. Modelling the Interactions of Soils, Climate, and Management for Grass Production in England and Wales. Agronomy 2021, 11, 677. https:// doi.org/10.3390/agronomy11040677

Academic Editor: Danilo Scordia

Received: 13 February 2021

Accepted: 30 March 2021

Published: 2 April 2021

Publisher's Note: MDPI stays neutral with regard to jurisdictional claims in published maps and institutional affiliations.

Copyright: (C) 2021 by the authors. Licensee MDPI, Basel, Switzerland. This article is an open access article distributed under the terms and conditions of the Creative Commons Attribution (CC BY) license (https:/ / creativecommons.org/licenses/by/ $4.0 /)$.

\begin{abstract}
This study examines the effectiveness of a model called LINGRA-N-Plus to simulate the interaction of climate, soil and management on the green leaf and total dry matter yields of ryegrass in England and Wales. The LINGRA-N-Plus model includes modifications of the LINGRA-N model such as temperature- and moisture-dependent soil nitrogen mineralization and differential partitioning to leaves and stems with thermal time from the last harvest. The resulting model was calibrated against the green leaf and total grass yields from a harvest interval $x$ nitrogen application experiment described by Wilman et al. (1976). When the LINGRA-N-Plus model was validated against total grass yields from nitrogen experiments at ten sites described by Morrison et al. (1980), its modelling efficiency improved greatly compared to the original LINGRA-N. High predicted yields, at zero nitrogen application, were related to soils with a high initial nitrogen content. The lowest predicted yields occurred at sites with low rainfall and shallow rooting depth; mitigating the effect of drought at such sites increased yields by up to $4 \mathrm{tha}^{-1}$. The results highlight the usefulness of grass models, such as LINGRA-N-Plus, to explore the combined effects of climate, soil, and management, like nitrogen application, and harvest intervals on grass productivity.
\end{abstract}

Keywords: LINGRA; nitrogen; soil moisture deficit; soil organic matter; water stress

\section{Introduction}

Grasslands in England and Wales are used to feed dairy cows, beef cattle, and sheep and effective grass management is a key determinant of farm income on most livestock farms. Grasslands also provide environmental benefits such as carbon storage, biodiversity maintenance and erosion control [1-3]. In the context of climate change, there is a need to determine the efficacy of adaptation strategies to increase the productivity and resilience of grass production, while also enhancing the essential ecosystem services they provide [4-6].

Based on modelled predictions, grassland productivity could be enhanced under future climate, i.e., rising temperatures and potentially longer cropping seasons [7]. However, reduced soil water availability in summer may also limit the growing season [8], reducing forage productivity and increasing the variability of yield [9]. In the short-term in England and Wales, Rounsevell et al. [10] predicted that climate change was unlikely to have a 
negative impact on grasslands, although, across Europe, the impact of climate change is likely to vary significantly between regions $[11,12]$.

Soil characteristics, such as soil type, depth, and texture, can affect grass production as they modify the level of soil water storage, nutrient retention, and soil organic matter content [13]. Research at Hurley in Southern England showed that perennial ryegrass could use soil water to a depth of about $90 \mathrm{~cm}$ [14]. Soils with high soil water storage capacity can moderate the effect of drought stress, with the exact effect dependent on site-specific climate and topography [15]. Soil moisture can also affect the level of microbial biomass and activity [8].

Two major management decisions that determine the capacity of grass to achieve its pedo-climatic production potential are the cutting or grazing intensity and nutrient addition. The frequency of grass harvests affects both the yield and partitioning of harvested green leaf and total dry mass. With long harvest intervals, the yield of green leaf tends to decrease, whilst total dry matter yields tend to increase reaching a plateau [16-18]. The frequency of cutting also affects leaf area, changing soil water extraction, with more frequent cuts progressively reducing regrowth, and severe defoliation reducing or temporally stopping root growth $[19,20]$. Thus, frequent cutting or over-grazing will eventually degrade the soil, reducing its organic matter content and thereby the water and nutrient availability.

The second major management decision affecting yield is the availability of nutrients. Grass is generally very responsive to nitrogen $(\mathrm{N})$ application as it increases the number of leaf primordia, leaf extension rate and the number of green leaves harvested per tiller [21].

In consideration of the above challenges, reliable quantitative methods are needed to predict grass growth and yield at the field- and farm-level [22]. Process-based plant growth models are important tools in agricultural and environmental research to predict local responses in time and space, and to assess the interactions of climate, soil, and agricultural practices with crop development and growth [23-25]. The algorithms used in the grass models typically include the best working assumptions of how the physiology and ecology of swards respond to environmental variables such as temperature, water and nitrogen availability, and carbon dioxide concentration in the atmosphere. Many of the available models are based on the LINGRA (LINTUL-GRASS) model, developed in the Netherlands [26,27]. A subsequent version of the model, LINGRA-N, was developed to describe the growth and development of perennial ryegrass under $\mathrm{N}$-limited growing conditions [28].

Hence, the objectives of this study are (1) to develop and calibrate the LINGRA-N model in relation to an existing nitrogen $x$ harvest interval study in Wales, (2) to validate the resulting model using historic grassland experiments from a range of sites in England and Wales, and (3) to demonstrate the difference in grass yields across a range of $\mathrm{N}$ availabilities and pedo-climatic conditions. We will discuss our results in the context of optimizing sustainable grassland management for different pedo-climatic conditions.

\section{Methodology}

\subsection{Model Development and Calibration}

The first stage was to create a working version of the LINGRA-N model in Microsoft Excel. Initial analyses were undertaken which demonstrated that our initial version of LINGRA-N gave similar results to those derived from the original version of the model produced by Wolf [28]. Starting from this basis, an updated model, called LINGRA-N-Plus [29], was developed and calibrated using the results from a nitrogen application $\mathrm{x}$ harvestinterval experiment on perennial ryegrass (Lolium perenne) described by Wilman et al. [17]. The experiment examined harvest intervals ranging from 21 to 70 days (Appendix ATable A1) and nitrogen application rates of 0,262 and $525 \mathrm{~kg} \mathrm{~N} \mathrm{ha}^{-1}$ at Aberystwyth in Wales in terms of their effect on the yields of green leaf, stem, inflorescence, and total dry matter. In developing and calibrating the model, three major changes were made: (1) a change in the calculation of nitrogen availability, (2) a thermal time approach was used to describe grass development, and (3) changes in the assumptions regarding the 
proportion of stems and dead leaves removed at each harvest. These modifications are briefly described in turn.

\subsubsection{Soil Nitrogen Availability}

The original LINGRA-N model [28] assumed that in the soil, a proportion of decomposable $\mathrm{N}$ compounds became available to the grass crop each day. Available $\mathrm{N}$ for the crop could come from the total soil mineral $\mathrm{N}$ available at the start of growing period $\left(N_{\text {mins }}\right)$ and from fertilizer application, and it was assumed that $70 \%$ of applied $\mathrm{N}$ could be recovered from the soil. In the LINGRA-N-Plus model, two additional sources were included, nitrogen from recalcitrant plant material $\left(N_{\mathrm{rpm}}\right)$ and nitrogen from decomposable plant material $\left(N_{\mathrm{dpm}}\right)$ [30]. The assumption in LINGRA-N-Plus is that the net mineralization of organic $\mathrm{N}\left(N_{\min }\right)$ is calculated by the first order kinetics using the two pools of mineralisable nitrogen, $N_{\mathrm{dpm}}$ and $N_{\mathrm{rpm}}$, where $T$ is the soil temperature (Equation (1)).

$$
N_{\min (\mathrm{t})}=N_{\min (\mathrm{t}-1)}+0.70 N_{\mathrm{fert}}+N_{\mathrm{rpm}} *\left[1-\exp \left(-k_{\mathrm{rpm}}(T)\right)_{\mathrm{t}}\right]+N_{\mathrm{dpm}} *\left[1-\exp \left(-k_{\mathrm{dpm}}(T)\right)_{\mathrm{t}}\right]
$$

The rate constants $\left(k_{\mathrm{rpm}}, k_{\mathrm{dpm}}\right)$ in Equation (1) can be determined from the soil temperature $\left(T ;{ }^{\circ} \mathrm{C}\right)$, the actual moisture content $(\theta)$, and the moisture contents at permanent wilting point $\left(\theta_{\mathrm{PWP}}\right)$ and field capacity $\left(\theta_{\mathrm{FC}}\right)$ according to the Arrhenius relationship (Equations (2) and (3); $[30,31])$.

$$
\begin{aligned}
& k_{\mathrm{rpm}}(T)=4.0 * 10^{9} * \exp \left(-\frac{8400}{T+273}\right) * \frac{\left(\theta-\theta_{\mathrm{PWP}}\right)}{\theta_{\mathrm{FC}}} \\
& k_{\mathrm{dpm}}(T)=5.6 * 10^{12} * \exp \left(-\frac{9800}{T+273}\right) * \frac{\left(\theta-\theta_{\mathrm{PWP}}\right)}{\theta_{\mathrm{FC}}}
\end{aligned}
$$

The amount of total soil $\mathrm{N}\left(\mathrm{kg} \mathrm{ha}^{-1}\right)$ per site, was calculated from the percentage of $\mathrm{N}$ in the top $20 \mathrm{~cm}$ of soil, assuming a bulk density of $1.2 \mathrm{~g} \mathrm{~cm}^{-3}$. The nitrogen in recalcitrant plant materials $\left(\mathrm{N}_{\mathrm{rpm}}\right)$ was assumed to comprise $2 \%$ of the total soil $\mathrm{N}[32,33]$, which in turn was derived from a reported measurement [34], while the nitrogen in decomposable plant materials $\left(N_{\mathrm{dpm}}\right)$ was assumed to be dependent on the previous land use, being $20 \mathrm{~kg} \mathrm{ha}^{-1}$ for previously arable land and $40 \mathrm{~kg} \mathrm{ha}^{-1}$ for previously permanent grassland sites [35]. The experiment described by Wilman et al. [17] was a recently cultivated grassland on a gley soil, so the $\mathrm{N}$ content is likely to have been high [36].

\subsubsection{Thermal Time Functions for Above-Ground Partitioning}

The original LINGRA-N model assumed that a constant proportion of the aboveground dry matter was partitioned to green leaves. In order for the LINGRA-N model to describe the decline in green leaf yields with increasing harvest intervals (HI; days), we included a dynamic function to describe the changing partitioning of above-ground biomass with time after each harvest. A thermal time approach was used that assumed variable allocations to green leaves, stem, and inflorescences based on the $\mathrm{BBCH}$ scale for grasses [37] (Appendix A-Table A2). The calibrated model assumes that until it reached the tillering to stem elongation stage (BBCH 21-30), the grass would partition $90 \%$ of the above-ground biomass to green leaves and 10\% to stems. By contrast, between grain filling and maturity (BBCH 65-90), the grass would partition $5 \%$ to leaf, $80 \%$ to stem, and $15 \%$ to seeds. Unlike the original LINGRA-N model, within the LINGRA-N-Plus, it was assumed that the development of the grass was reset to tillering (BBCH 21) immediately after harvest.

\subsubsection{Composition of the Harvested Yield}

The results from Wilman et al. [17] demonstrate that a proportion of the total harvested biomass comprises stems and dead leaves, and that the proportion of dead leaves increased with the time from the last harvest. In the final calibration of LINGRA-N-Plus, for each cut, 
we assumed that the same proportion of the standing stem and green leaf was harvested. We also assumed that the amount of dead leaf (expressed as a proportion of the total weight of green leaves and stems) was equal to $0.0035^{*}(\mathrm{HI}-21)$. It was assumed that when the harvest interval was greater than 70 days, the proportion of dead leaf remained at 0.1715. Implementing the above changes, the results from the LINGRA-N-Plus model were compared to the yield measurements reported by Wilman et al. [17].

\subsection{Validation of LINGRA-N-Plus}

The calibrated model, called LINGRA-N-Plus, was validated using the National Grassland Manuring Trial GM20 for a late flowering perennial ryegrass [34], which investigated the response of ryegrass to $\mathrm{N}$ application rates of $0,150,300,450,600$, and $750 \mathrm{~kg} \mathrm{~N}^{-1}$, at a 28-day cutting interval from May to September or October (Appendix A-Table A3). The yields were measured in terms of total dry matter. For the validation, only $\mathrm{N}$ applications up to $450 \mathrm{~kg} \mathrm{~N} \mathrm{ha}^{-1}$ were considered (Appendix A-Table A4).

The selected validation sites covered 10 locations across England and Wales (Figure 1). The level of drought stress experienced by the grass at each site is a function of the climate and soil conditions. Rainfall across the 10 sites in 1973 ranged from $408 \mathrm{~mm}$ at Cambridge in Eastern England to $869 \mathrm{~mm}$ at Newton Abbot in South-West England (Table 1). The soil texture across the 10 sites ranged from sandy loam to clay loam (Table 2) and the clay contents ranged from $10 \%$ at Newton Abbot to 53\% at Winchester (Table 3). The rooting depths ranged from $45 \mathrm{~cm}$ at High Mowthorpe to $100 \mathrm{~cm}$ at six of the sites, and the available water capacity (AWC) within the rooting depth ranged from 24 to $188 \mathrm{~mm}$ (Table 1).

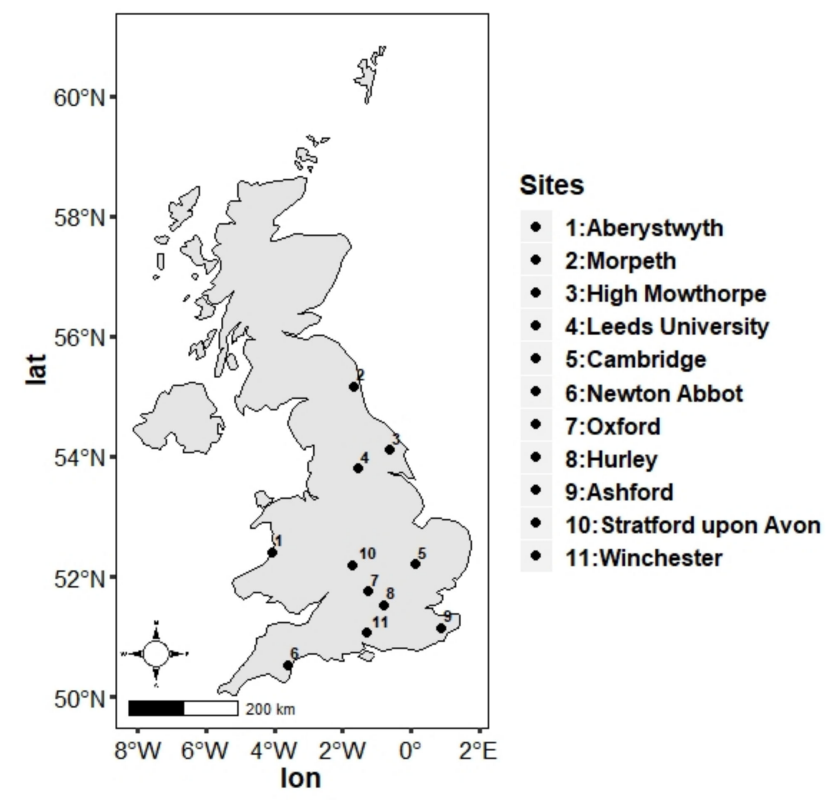

Figure 1. Grassland yield data for calibration were derived from Aberystwyth (Site 1; [17]) and validation data from 10 other sites in England [34].

The AWC at each site was derived from the soil water release curves (water contents at saturation, field capacity, and permanent wilting point; Appendix A-Table A5). The plant AWC of the profile was assumed to be the sum of soil moisture between field capacity and permanent wilting point accumulated across the horizons accessible to roots. The sites were also characterized in terms of a Drought Stress Index (DSI) [38], defined as the outcome of subtracting the AWC from the potential soil moisture deficit (PSMD; Equation (4)) [39], with positive values indicating "droughty" conditions. If the sum was negative, the site was categorized as "non-droughty" and the DSI was assumed to be zero.

$$
P S M D_{[i]}=P S M D_{[i-1]}+E T_{[i]}-R_{[i]}
$$


where $E T_{[\mathrm{i}]}$ and $R_{[\mathrm{i}]}$ refer to crop evapotranspiration and rainfall amount for the particular day [i], respectively.

Table 1. Annual rainfall, mean annual temperature, and total annual solar radiation for the calibration site of Aberystwyth in 1973, and for the 10 validation sites in 1972 and 1973, the rooting depth, the available water capacity (AWC), the annual maximum potential soil moisture deficit (PSMD), and a Drought Stress Index (DSI).

\begin{tabular}{|c|c|c|c|c|c|c|c|c|c|c|c|c|}
\hline \multirow[t]{2}{*}{ Site } & \multicolumn{2}{|c|}{$\begin{array}{c}\text { Total } \\
\text { Rainfall } \\
(\mathrm{mm})\end{array}$} & \multicolumn{2}{|c|}{$\begin{array}{c}\text { Mean } \\
\text { Temperature } \\
\left({ }^{\circ} \mathrm{C}\right)\end{array}$} & \multicolumn{2}{|c|}{$\begin{array}{c}\text { Total } \\
\text { Radiation } \\
\left(\mathrm{GJ} \mathrm{m}^{-2}\right)\end{array}$} & \multirow[t]{2}{*}{$\begin{array}{l}\text { Rooting } \\
\text { Depth } \\
\text { (cm) }\end{array}$} & \multirow[t]{2}{*}{$\begin{array}{l}\text { AWC } \\
\text { (mm) }\end{array}$} & \multicolumn{2}{|c|}{$\begin{array}{c}\text { Max } \\
\text { PSMD } \\
(\mathrm{mm})\end{array}$} & \multicolumn{2}{|c|}{$\begin{array}{l}\text { DSI } \\
(\mathrm{mm})\end{array}$} \\
\hline & 1972 & 1973 & 1972 & 1973 & 1972 & 1973 & & & 1972 & 1973 & 1972 & 1973 \\
\hline Aberystwyth & - & 1055 & - & 9.8 & - & 3.16 & 125 & 160 & - & 74 & - & 0 \\
\hline Morpeth & 577 & 522 & 8.0 & 8.4 & 2.78 & 2.87 & 100 & 140 & 125 & 87 & 0 & 0 \\
\hline High Mowthorpe & 633 & 613 & 7.8 & 8.2 & 2.87 & 2.93 & 45 & 81 & 120 & 75 & 39 & 0 \\
\hline Leeds & 544 & 505 & 8.8 & 9.2 & 2.81 & 3.26 & 100 & 188 & 107 & 116 & 0 & 0 \\
\hline Cambridge & 419 & 408 & 9.6 & 9.9 & 3.24 & 3.51 & 60 & 24 & 220 & 217 & 196 & 193 \\
\hline Newton Abbot & 1341 & 869 & 9.9 & 10.4 & 3.42 & 3.42 & 100 & 128 & 91 & 73 & 0 & 0 \\
\hline Oxford & 576 & 495 & 9.9 & 10.2 & 3.01 & 3.42 & 100 & 180 & 225 & 202 & 45 & 22 \\
\hline Hurley & 596 & 548 & 9.5 & 9.7 & 3.33 & 3.28 & 60 & 60 & 226 & 141 & 166 & 81 \\
\hline Ashford & 717 & 583 & 9.1 & 9.6 & 3.29 & 3.54 & 90 & 115 & 170 & 209 & 55 & 94 \\
\hline Stratford & 593 & 482 & 9.1 & 9.5 & 3.47 & 3.54 & 100 & 160 & 75 & 54 & 0 & 0 \\
\hline Winchester & 813 & 546 & 9.4 & 10.3 & 3.22 & 3.54 & 100 & 160 & 150 & 52 & 0 & 0 \\
\hline
\end{tabular}

AWC: Available water capacity at the start of the year; PSMD: Potential soil moisture deficit; DSI: Drought stress index = PSMD-AWC; if $-\mathrm{AWC}<0$, then the stress index was assumed to be zero.

The level of recalcitrant plant material $\mathrm{N}$ ranged from 86 to $163 \mathrm{~kg} \mathrm{~N} \mathrm{ha}^{-1}$ (Table 2). For most sites, Morrison et al. [34] provided values of the total soil $\mathrm{N}$ content (Table 2). If data, were not available, then other references were used. For example, the soil at Morpeth in Northeast England, belongs to the Dunkeswick Series which is classified as a "gley" [40,41]. The LINGRA-N-Plus model also includes a total mineral soil N available at start of growth period ( $\left.N_{\text {mins }}\right)$, which was assumed to be $75 \mathrm{~kg} \mathrm{ha}^{-1}$ for the permanent grassland sites (Aberystwyth and Morpeth) and zero for the arable and ley-arable sites. The above values compare to a calculated mean annual contribution of $\mathrm{N}$ from the soil of $60 \mathrm{~kg} \mathrm{ha}^{-1}$ reported by Morrison et al. [34].

Table 2. The soil series, texture, previous cropping, total nitrogen $(\mathrm{N})$ content in the top $20 \mathrm{~cm}$ of soil, and the assumed level of recalcitrant plant material nitrogen $\left(N_{\mathrm{rpm}}\right)$ at the calibration site in Aberystwyth and 10 validation sites.

\begin{tabular}{|c|c|c|c|c|c|}
\hline \multirow{2}{*}{ Site } & \multirow{2}{*}{ Series } & \multirow{2}{*}{ Soil Texture } & \multirow{2}{*}{ Previous Crop * } & \multirow{2}{*}{$\begin{array}{c}\text { Total Soil N } \\
\left.\text { (kg ha }^{-1}\right)\end{array}$} & \multirow{2}{*}{$\begin{array}{c}N_{\mathrm{rpm}} \\
\left.\text { (kg ha-1) }^{-1}\right)\end{array}$} \\
\hline & & & & & \\
\hline Aberystwyth & Conway \# & Silt & PG & 8160 & 163 \\
\hline Morpeth & Dunkeswick & Sandy loam over silt loam & PG & 7920 & 163 \\
\hline H. Mowthorpe & Andover & Silt to silty clay & AR, PR & 8400 & 158 \\
\hline Leeds & Aberford & Clay loam over clay & AR & 4800 & 96 \\
\hline Cambridge & Landbeach & Sandy loam over sandy clay loam & $\mathrm{AR}$ & 6960 & 139 \\
\hline N. Abbot & HighWeek & Silt & Ley, AR & 8160 & 163 \\
\hline Oxford & Thames & Loam & $\mathrm{AR}$ & 6960 & 139 \\
\hline Hurley & Frilsham & Sandy loam & AR & 4320 & 86 \\
\hline Ashford & Thorne & Silt loam & AR & 5520 & 110 \\
\hline Stratford & Evesham & Clay loam & Ley, AR & 8160 & 163 \\
\hline Winchester & Winchester & Clay loam & $\mathrm{AR}$ & 6240 & 125 \\
\hline
\end{tabular}

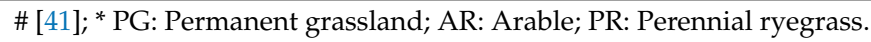

Using the above information, the LINGRA-N-Plus model was used to predict the total dry matter yield at each of the 10 validation sites. Statistical analysis was carried out using $\mathrm{R}$ [42]. Linear regression was described using the $R^{2}$, root mean square error (RMSE), and modelling efficiency (EF). EF provides a comparison of the efficiency of the chosen model to the efficiency of describing the data as the mean of the observations [43]. Values for EF can be positive or negative with a maximum value of 1 . A positive value indicates that the simulated values describe the trend in the measured data better than the mean of the 
observations. Smaller and negative values indicate that the simulated values describe the data less well compared to the mean of the observations.

\subsection{Analysis of Soil and Climate Factors}

The last part of analysis comprised an analysis of the effects of climate and soil factors, water, and $\mathrm{N}$ availability, on the predicted yields. The sites were grouped according to the value of soil organic carbon (SOC) divided by the clay content, which is a potential index of soil health $[44,45]$. The values for SOC were derived from soil organic matter (SOM) values reported by Morrison et al. [34] (Table 3). As no SOM content was reported for Morpeth, we assumed a mean of $10.5 \%$, the mid-point of typical SOM contents for the Dunkeswick series [40]. A SOM content of $10.5 \%$ was assumed for the gley soil (Conway series) at the Aberystwyth site $[17,41]$. This study used the same classes for the SOC/clay values as Prout et al. [45], with values $>0.12,0.12-0.10,0.10-0.07$ and $<0.07$ representing the boundaries between "very good", "good", "moderate" and "degraded" levels of a soil structural condition/soil health.

Table 3. The soil organic matter (SOM), Total nitrogen (\%), the resulting C:N ratio, the proportion clay, SOC/clay and its designation for the calibration site in Aberystwyth and 10 validation sites.

\begin{tabular}{|c|c|c|c|c|c|c|}
\hline \multirow{2}{*}{ Site } & SOM & Total N & $\mathrm{C}: \mathrm{N}^{*}$ & Clay $^{+}$ & SOC/Clay * & $\begin{array}{c}\text { SOC/Clay } \\
\text { Designation }\end{array}$ \\
\hline & $(\%)$ & $(\%)$ & & $(\%)$ & & \\
\hline Aberystwyth & 10.5 & 0.34 & 18.0 & 31 & 0.20 & Very good \\
\hline Morpeth & 10.5 & 0.33 & 18.5 & 24 & 0.25 & Very good \\
\hline H. Mowthorpe & 6.2 & 0.35 & 10.3 & 41 & 0.09 & Moderate \\
\hline Leeds & 3.2 & 0.20 & 9.3 & 25 & 0.07 & Moderate \\
\hline Cambridge & 4.5 & 0.29 & 9.0 & 12 & 0.22 & Very good \\
\hline N. Abbot & 5.6 & 0.34 & 9.6 & 10 & 0.33 & Very good \\
\hline Oxford & 4.8 & 0.29 & 9.6 & 52 & 0.05 & Degraded \\
\hline Hurley & 2.6 & 0.18 & 8.4 & 26 & 0.06 & Degraded \\
\hline Ashford & 3.7 & 0.24 & 9.0 & 14 & 0.15 & Very good \\
\hline Stratford & 5.9 & 0.34 & 10.1 & 52 & 0.06 & Degraded \\
\hline Winchester & 3.9 & 0.26 & 8.7 & 53 & 0.04 & Degraded \\
\hline
\end{tabular}

* Based on a SOM to SOC conversion factor of 1.72. ${ }^{+}$Derived as the average value per soil series across soil profile-[41]".

\section{Results}

\subsection{Development and Calibration of the Model}

Using the weather and soil conditions at Aberystwyth, the LINGRA-N-Plus model predicted that the maximum green leaf yield occurred at cutting intervals of 21 and 28 days, and a maximum dry matter yield at an interval of 70 days (Figure 2; Appendix ATable A6), matching the experimental evidence [17]. With no $\mathrm{N}$ application, at a harvest interval of 21 days, the predicted and observed total dry biomass yields were $4.66 \mathrm{tha}^{-1}$ and $4.73 \mathrm{tha}^{-1}$, respectively.

The corresponding predicted and observed total dry biomass yields with $262 \mathrm{~kg} \mathrm{~N} \mathrm{ha}{ }^{-1}$ were $10.20 \mathrm{t} \mathrm{ha}^{-1}$ and $9.36 \mathrm{t} \mathrm{ha}^{-1}$ and the change in total dry matter yield and green leaf yield with increasing HI was well described by the model (Figure 2). At a nitrogen application of $525 \mathrm{~kg} \mathrm{~N} \mathrm{ha}^{-1}$, the predicted and actual yields of $10.30 \mathrm{t} \mathrm{ha}^{-1}$ and $10.85 \mathrm{tha}^{-1}$ were also similar. 
(a) $0 \mathrm{~kg} \mathrm{~N} \mathrm{ha-1}$

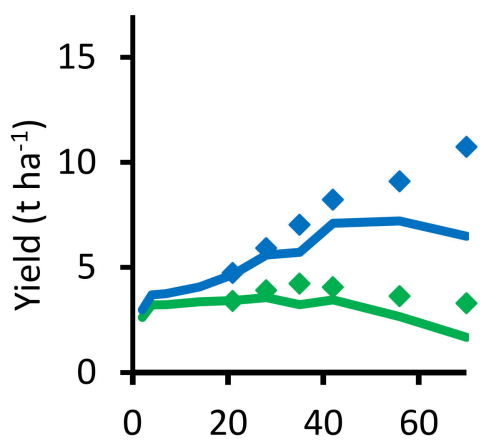

(b) $262 \mathrm{~kg} \mathrm{~N} \mathrm{ha-1}$

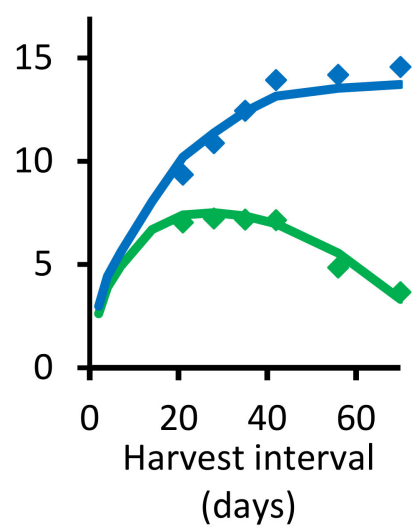

(c) $525 \mathrm{~kg} \mathrm{~N} \mathrm{ha}^{-1}$

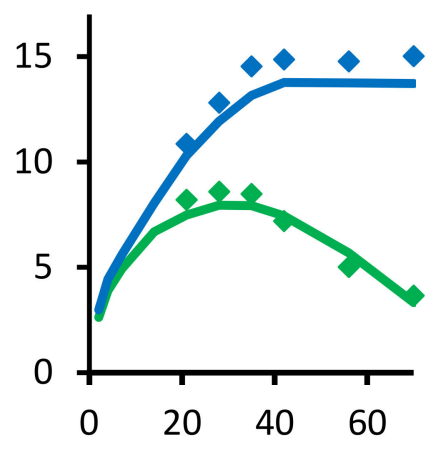

Figure 2. Effect of harvest interval (March to October) on the green leaf (green highlighted) and total dry biomass (blue highlighted) yields at Aberystwyth as observed by Wilman et al. [17] (data points) and predicted by LINGRA-N-Plus (solid lines).

Overall a correlation of $94 \%$ was obtained between the observed and the predicted green leaf and total yields modelled using LINGRA-N-Plus at applications of 0, 262 and $525 \mathrm{~kg} \mathrm{~N} \mathrm{ha}^{-1}$ (Figure 3).

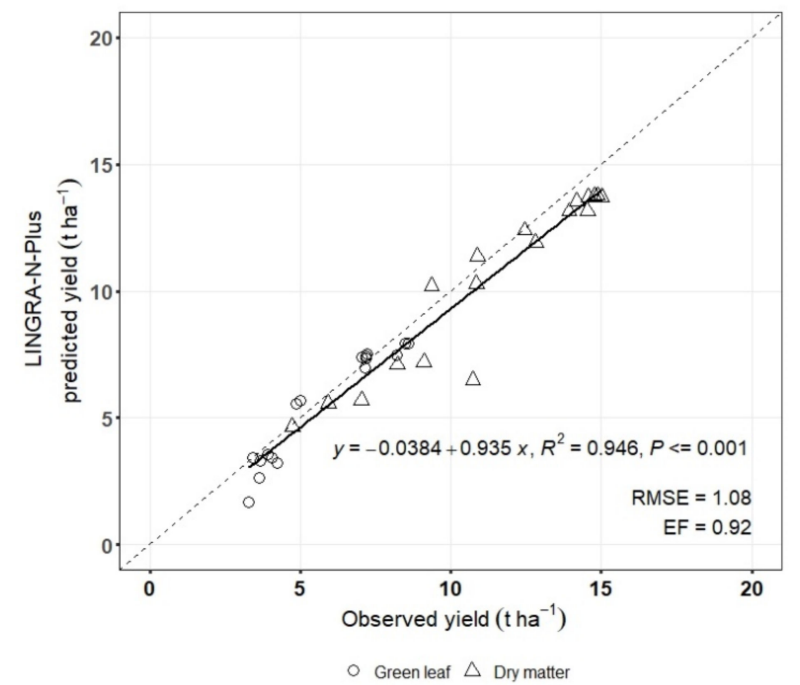

Figure 3. Linear regression analysis of predicted and observed dry matter yields of green leaf $(\bigcirc)$ and total dry matter $(\triangle)$ from Wilman et al.'s [17] experiment at Aberystwyth. Dashed line: 1:1; RMSE: Root Mean Square Error; EF: Modelling efficiency.

\subsection{Validation of the LINGRA-N-Plus Model (Morrison Experimental Data)}

Overall, the LINGRA-N-Plus model predicted similar yields to those reported by Morrison et al. [34] (Appendix A-Table A7). The level of correlation $\left(R^{2}\right)$ between the predicted and actual results was $77 \%$ in 1972 and $84 \%$ in 1973 (Figure 4). The root mean square error (RMSE) was $2.45 \mathrm{t} \mathrm{ha}^{-1}$ in 1972 and $1.98 \mathrm{t} \mathrm{ha}^{-1}$ in 1973. The modelling efficiency (EF) ranged from 0.58 in 1972 to 0.65 in 1973 (Figure 4). 


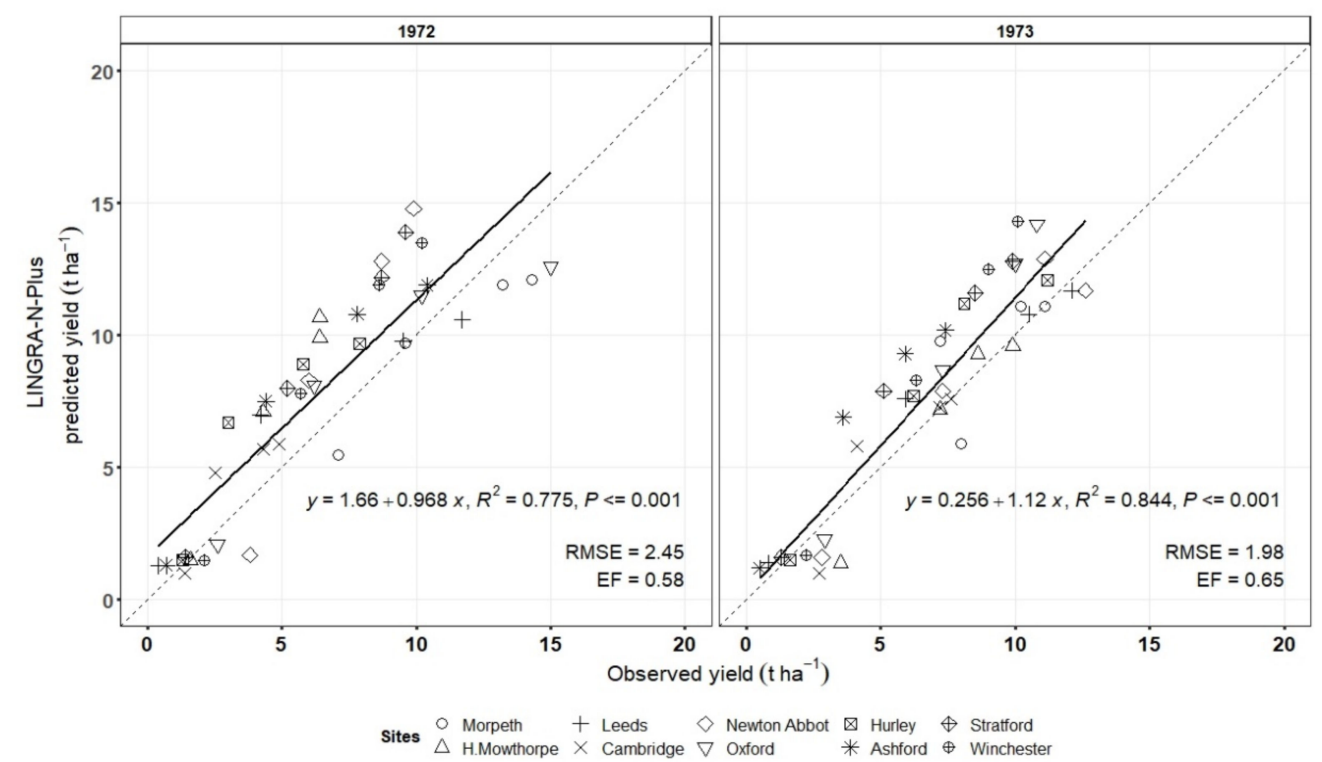

Figure 4. Linear regression analysis of the predicted yields using the LINGRA-N-Plus model with observed yields from Morrison et al.'s [34] experiment (Dashed line: 1:1; RMSE: root mean square error; EF: Modelling efficiency).

A feature of the results reported by Morrison et al. [34] is high yields at zero nitrogen application for the site at Morpeth of $7.1 \mathrm{t} \mathrm{ha}^{-1}$ in 1972 and $8.0 \mathrm{tha}^{-1}$ in 1973 . For this situation, the LINGRA-N-Plus predicted 5.5 and $5.9 \mathrm{t} \mathrm{ha}^{-1}$, respectively (Appendix ATable A7). Like the calibration at Aberystwyth, Morpeth had been a permanent grassland site with high SOM content, and hence a high initial soil mineral nitrogen of $75 \mathrm{~kg} \mathrm{~N} \mathrm{ha}^{-1}$ was assumed.

\subsection{Comparison of the Results from LINGRA with Those from LINGRA-N-Plus}

Comparing the yields simulated using LINGRA-N and LINGRA-N-Plus, showed that for the calibration data set [17] the model improvement was considerable $\left(R^{2}\right.$ of $94 \%$ compared to 74\% using LINGRA-N; Table 4). The RMSE with LINGRA-N of $2.22 \mathrm{tha}^{-1}$ was reduced to $1.08 \mathrm{t} \mathrm{ha}^{-1}$ with LINGRA-N-Plus. The EF increased from 0.67 to 0.92 . When comparing the linear regression results for LINGRA-N and LINGRA-N-Plus, it is evident that the original LINGRA-N model was unable to accurately predict the yields described in the Morrison experimental data, resulting in negative modelling efficiency (EF) and a very high RMSE (3.21-3.91 $\mathrm{t} \mathrm{ha}^{-1}$; Table 4).

Table 4. Linear regression summary for LINGRA-N and LINGRA-N-Plus against the observed green leaf and total dry matter yields ( $\mathrm{ha}^{-1}$ ) at Aberystwyth in 1973 [17] and against total dry matter yields ( $\mathrm{ha}{ }^{-1}$ ) for the Morrison et al. [34] dataset in 1972 and 1973.

\begin{tabular}{llllllc}
\hline \multirow{2}{*}{$\begin{array}{l}\text { Descriptive } \\
\text { Statistics }\end{array}$} & \multicolumn{3}{c}{ Wilman et al. } & \multicolumn{2}{c}{ Morrison et al. } & \multicolumn{2}{c}{ Morrison et al. } \\
\cline { 2 - 7 } & LINGRA-N-Plus & LINGRA-N & LINGRA-N-Plus & LINGRA-N & LINGRA-N-Plus & LINGRA-N \\
\cline { 2 - 7 } & -0.03 & 0.74 & 0.25 & -0.65 & 1.66 & 1.32 \\
Constant & $0.93^{* * *}$ & $0.79^{* * *}$ & $1.12^{* * *}$ & $1.38^{* * *}$ & $0.96^{* * *}$ & $1.21^{* * *}$ \\
Slope & 0.946 & 0.748 & 0.844 & 0.821 & 0.775 & 0.743 \\
$R^{2}$ & 1.08 & 2.22 & 1.98 & 3.21 & 2.45 & 3.91 \\
RMSE & 0.92 & 0.67 & 0.65 & -0.06 & 0.58 & -0.06 \\
EF & & &
\end{tabular}


At $0 \mathrm{~kg} \mathrm{~N} \mathrm{ha}^{-1}$, LINGRA-N-Plus was unable to approach the observed grass yields at the same level of precision as for $\mathrm{N}$ applications greater than zero. A linear regression analysis per $\mathrm{N}$ application, showed that LINGRA-N-Plus resulted in improved predictions $\left(\mathrm{RMSE}=1.57 \mathrm{t} \mathrm{ha}^{-1} ; R^{2}=0.821 ; \mathrm{EF}=0.57\right)$ at all $\mathrm{N}$ applications compared to the original LINGRA-N model $\left(\mathrm{RMSE}=1.81 \mathrm{t} \mathrm{ha}^{-1} ; R^{2}=0.754 ; \mathrm{EF}=0.43\right.$; Appendix A-Table A8).

\subsection{Climate, Soil, and Nitrogen Interactions on Grass Yields}

In the last part of the analysis, the 10 experimental sites were grouped according to year and the Drought Stress Index (DSI). The analysis of variance for all sites highlighted that there was a significant DSI effect $(p<0.05)$ on the observed dry matter yields (Appendix ATables A9 and A10). The multiple comparisons indicated high grass yields at Morpeth in both years, and low yields at Cambridge, Ashford, and Leeds.

In 1972 at the same $\mathrm{N}$ application of $300 \mathrm{~kg} \mathrm{~N}$ ha $^{-1}$ under "non-droughty" conditions Morpeth showed higher yields (13.2 $\mathrm{t} \mathrm{ha}^{-1}$ ) than Leeds, Newton Abbot, Stratford, and Winchester (8.6-9.5 $\mathrm{t} \mathrm{ha}^{-1}$ ). Winchester designated a "non-droughty" site, receiving $300 \mathrm{~kg} \mathrm{~N} \mathrm{ha}^{-1}$ resulted in significant higher yields $\left(8.6 \mathrm{t} \mathrm{ha}^{-1}\right)$ than at Cambridge, designated a "droughty" site, even at an application of $450 \mathrm{~kg} \mathrm{~N} \mathrm{ha}^{-1}\left(4.9 \mathrm{t} \mathrm{ha}^{-1}\right)$. In 1972, at a zero-nitrogen application, with the exception of Morpeth, the yields at "non-droughty" and "droughty" sites were similar. The reported rooting depth at Morpeth of $100 \mathrm{~cm}$ was higher than that at some sites and the mean temperature $\left(8^{\circ} \mathrm{C}\right)$ was relatively low. However, the major difference, particularly with no nitrogen application, was the assumption of a high initial soil nitrogen content.

In 1973 at $300 \mathrm{~kg} \mathrm{~N}$ ha $^{-1}$ amongst the "non-droughty" sites, Newton Abbot resulted in significantly higher yields $\left(12.6 \mathrm{t} \mathrm{ha}^{-1}\right)$ than Winchester, High Mowthorpe and Stratford (8.5-9.0 $\mathrm{t} \mathrm{ha}^{-1}$ ) (Appendix A-Table A10). Newton Abbot's annual rainfall and solar radiation was $869 \mathrm{~mm}$ and $3.42 \mathrm{GJ} \mathrm{m}^{-2}$, respectively, which was greater than that High Mowthorpe's (613 mm, $2.93 \mathrm{GJ} \mathrm{m}^{-2}$ ) (Table 1$)$. In addition, the higher yield at Newton Abbot was associated with a high SOC/clay value (Table 3), compared to lower SOC/clay values at High Mowthorpe, Stratford and Winchester.

It is also noteworthy that in 1972 and at $150 \mathrm{~kg} \mathrm{~N} \mathrm{ha}^{-1}$, Morpeth with a "very good" SOC/clay and "non-droughty" conditions, resulted in higher yields $\left(9.6 \mathrm{t} \mathrm{ha}^{-1}\right)$ than those in Winchester and Stratford (5.2-5.7 $\mathrm{t} \mathrm{ha}^{-1}$ ) also with non-droughty conditions, but with "degraded" SOC/clay values. The overall effect of different levels of drought stress on grass yields (Table 5), demonstrates that dry matter yields were typically higher at "nondroughty" rather than "droughty" sites for all $\mathrm{N}$ applications, apart from $0 \mathrm{~kg} \mathrm{~N} \mathrm{ha}^{-1}$ where no statistical effect was apparent.

Table 5. Effect of "droughty" and "non-droughty" sites on observed total dry matter yields in 1972 and 1973 reported by Morrison et al. [34].

\begin{tabular}{|c|c|c|c|c|}
\hline \multirow{3}{*}{$\begin{array}{l}\text { N Applied } \\
\left(\mathrm{kg} \mathrm{Nha}^{-1}\right)\end{array}$} & \multicolumn{4}{|c|}{ Total Harvested Yield (t ha ${ }^{-1}$ ) } \\
\hline & \multicolumn{2}{|c|}{1972} & \multicolumn{2}{|c|}{1973} \\
\hline & "Non-Droughty" Sites & "Droughty" Sites & "Non-droughty" Sites & "Droughty" Sites \\
\hline 0 & $2.96 \mathrm{de}$ & $1.52 \mathrm{e}$ & $3.10 \mathrm{e}$ & $1.92 \mathrm{e}$ \\
\hline 150 & $6.14 \mathrm{c}$ & $4.08 \mathrm{~d}$ & $6.50 \mathrm{~cd}$ & $5.30 \mathrm{~d}$ \\
\hline 300 & $9.74 \mathrm{ab}$ & $6.90 c$ & $10.05 \mathrm{a}$ & $7.80 \mathrm{bc}$ \\
\hline 450 & $11.14 \mathrm{a}$ & $8.92 \mathrm{~b}$ & $10.55 \mathrm{a}$ & $9.25 \mathrm{ab}$ \\
\hline
\end{tabular}

Same letters per year indicate not significantly different $($ at $p<0.05)$.

Another output of the model is the estimate of the incremental $\mathrm{N}$ uptake efficiency (NUpE) which was defined as the $\mathrm{N}$ uptake between two levels of application, divided by the change in $\mathrm{N}$ application. Between 0 and $150 \mathrm{~kg} \mathrm{~N}^{-1}$, the NUpE at each site (with the exception of Morpeth) ranged from 0.76 to $0.89 \mathrm{~kg} \mathrm{~N}$ uptake (kg N applied) ${ }^{-1}$. As the $\mathrm{N}$ rate was further increased (with the exception of Morpeth), the NUpE declined to $0.41-0.46 \mathrm{~kg} \mathrm{~kg}^{-1}$ between 150 and $300 \mathrm{~kg} \mathrm{~N} \mathrm{ha}^{-1}$, and to $0.12-0.32 \mathrm{~kg} \mathrm{~kg}^{-1}$ between 
300 and $450 \mathrm{~kg} \mathrm{~N} \mathrm{ha}^{-1}$ (Table 6). $\mathrm{N}$ uptake and incremental $\mathrm{N}$ uptake efficiency for the remaining sites, were similar with those at Hurley (Appendix A-Table A11).

Table 6. Nitrogen uptake and incremental N uptake efficiency for five selected sites and four N applications in 1973.

\begin{tabular}{|c|c|c|c|c|c|c|}
\hline & $\begin{array}{l}\text { N Application } \\
\left(\mathbf{k g ~ N ~ h a ~}{ }^{-1}\right)\end{array}$ & Morpeth * & $\begin{array}{l}\text { High } \\
\text { Mowthorpe }\end{array}$ & Cambridge & Oxford & Hurley \\
\hline N uptake & 0 & 39 & 24 & 13 & 32 & 21 \\
\hline \multirow{3}{*}{$\left(\mathrm{kg} \mathrm{N} \mathrm{ha}{ }^{-1}\right)$} & 150 & 215 & 128 & 115 & 135 & 124 \\
\hline & 300 & 296 & 233 & 196 & 239 & 228 \\
\hline & 450 & 296 & 266 & 225 & 343 & 333 \\
\hline Incremental $\mathrm{N}$ & 0 to 150 & 0.48 & 0.81 & 0.89 & 0.76 & 0.83 \\
\hline uptake efficiency & 150 to 300 & 0.27 & 0.45 & 0.41 & 0.44 & 0.46 \\
\hline$\left(\operatorname{kg~N}(\operatorname{kg~N})^{-1}\right)$ & 300 to 450 & 0.00 & 0.12 & 0.13 & 0.30 & 0.32 \\
\hline
\end{tabular}

* Morpeth: assumed $75 \mathrm{~kg}$ soil mineral $\mathrm{N} \mathrm{ha}^{-1}$ at the start of the season.

\section{Discussion}

The results are discussed in terms of the objectives of the study: model improvement and calibration and validation of the LINGRA-N-Plus model, the effects of climate, soil and their interaction with management, harvest interval, and nitrogen availability on crop yields, and finally examination of how quantitative evaluation can improve grassland management.

\subsection{Improvement and Validation of the Model}

The original LINGRA-N model was developed to simulate the growth of frequently cut and intensively managed, i.e., $\mathrm{N}$-fertilized grassland, such as found in the Netherlands. In practice, much of grassland in England and Wales is not as frequently cut and less fertilized, and therefore $\mathrm{N}$ availability is often a limitation to growth, dependent on $\mathrm{N}$-mineralization. Therefore, we added in LINGRA-N-Plus a modified soil $\mathrm{N}$ availability function. Together with the differential partitioning of above-ground dry matter and updated algorithms to describe the amount of stem and dead leaves in the harvested dry matter, these changes resulted in improved grass yield predictions for both the calibration [17] and validation data [34]. In particular, the improved model was able to describe the plateauing of total dry matter yields as the harvest interval increased. It was also able to describe the peak in the yield of green leaf at an interval of 21-28 days. The practice of harvesting the grass at an interval of 21-28 days during the main growing season is a feature of intensive grazing systems for dairy cattle in England and Wales [21,46].

The LINGRA-N-Plus model sometimes underestimated the yields from non-fertilized plots, for example at Aberystwyth (Appendix A-Table A6) and Morpeth (Appendix ATable A7) where the soil had a high soil organic matter content. However, LINGRA-N-Plus had a lower bias compared to the original LINGRA-N (Appendix A-Table A8). The underestimated yields could be a result of underestimates of the $\mathrm{N}$ pools, as such soils can show a high level of organic $\mathrm{N}$ turnover due to the large microbial biomass [36].

The LINGRA-N-Plus was also able to predict the total dry matter yield. Qi et al. [24] reported the development at Rothamsted of a LINGRA-based model of grass growth to describe the total dry matter yield of different types of grassland in the UK. This model when calibrated against a subset of the same experimental data [34] resulted in a mean RMSE of $1.58 \mathrm{tha}^{-1}$. Although different sites were modelled by Qi et al. [24] and the current study, LINGRA-N-Plus showed a similar response with an average RMSE of $1.83 \mathrm{t} \mathrm{ha}^{-1}$, whilst the original LINGRA-N showed an average RMSE of $3.11 \mathrm{t} \mathrm{ha}^{-1}$.

\subsection{Effect of Climate, Soil, Harvest Interval and Nitrogen on Yields}

The LINGRA-N-Plus model allows the determination of the effect of drought stress on yields as the user can set the level of drought stress in the model to zero. The results 
show that a curvilinear relationship between the predicted yield reduction and the DSI value (potential soil moisture deficit minus the available water capacity; Figure 5).

The three sites showing the largest drought response were all based in eastern part of England: Cambridge, Hurley, and Ashford (Figure 5), whilst the remaining sites showed minimal or no response (Appendix A-Table A12). The yield loss due to drought at Cambridge was 3.30-4.05 $\mathrm{t} \mathrm{ha}^{-1}$, compared to $0.25-2.27 \mathrm{tha}^{-1}$ at Hurley, and 0.58-1.50 $\mathrm{tha}^{-1}$ at Ashford. The lower response at Hurley in $1973\left(0.25 \mathrm{t} \mathrm{ha}^{-1}\right)$ than in $1972\left(2.27 \mathrm{t} \mathrm{ha}^{-1}\right)$ is associated with a lower soil moisture deficit $(141 \mathrm{~mm})$ in 1973 than in $1972(226 \mathrm{~mm}$; Table 1). In England and Wales, those locations which are furthest west tend to have small PSMDs and hence are less likely to demonstrate yield losses due to drought.

A well-calibrated model can be useful in examining the key effects of climate, soil type, and nitrogen availability on yields. The lowest observed and predicted yields in the Morrison et al. [34] data were obtained at Cambridge, which was the driest site with shallow rooting to a depth of $60 \mathrm{~cm}$, compared to $100 \mathrm{~cm}$ at most other sites. Dry soil conditions have a direct effect on the soil water balance, but drought can also limit yield by reducing $\mathrm{N}$ uptake by the crop [47-49]. The effect of drought on grass yields in England and Wales is likely to increase in coming decades as climate change is expected to result in higher summer temperatures and more frequent summer droughts [50].

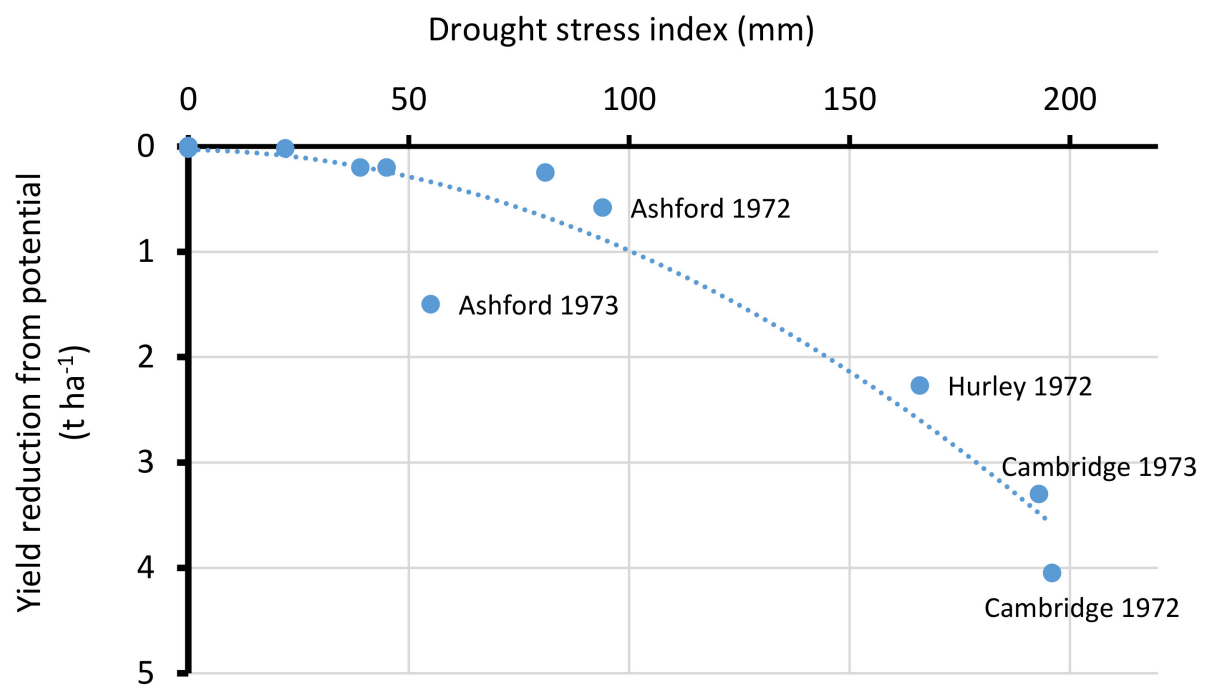

Figure 5. Modelled effect of the level of drought stress (defined as the potential soil moisture deficit minus the available water capacity) on the reduction in total dry matter yield, relative to the potential.

In addition to being a dry site, the soil series at Cambridge (Landbeach) comprises a non-alluvial permeable topsoil without significant clay enrichment [41]. This lack of clay, combined with the shallow rooting depth, results in a low available water capacity. In the UK, irrigation of grass is generally uneconomic except for the most intensively managed grazing systems [51]. One method to reduce the effect of drought would be to increase the rooting depth of the grass, perhaps by selecting deeper rooting varieties or by removing barriers to deeper root growth (such as an impermeable soil layer). Although not considered by the model, there is also the potential to include deeper rooting forage species as a mixture with the ryegrass. By using the LINGRA-N-Plus model, and assuming a consistent $\mathrm{N}$ application of $300 \mathrm{~kg} \mathrm{~N} \mathrm{ha}^{-1}$ and a harvest interval of 28 days, increasing the rooting depth at Cambridge from $60 \mathrm{~cm}$ to $90 \mathrm{~cm}$ was predicted to increase yields from $7.3 \mathrm{t} \mathrm{ha}^{-1}$ to $8.4 \mathrm{t} \mathrm{ha}^{-1}$ (Table 7). A second way to increase total dry matter yield could be to increase the harvest interval. However, assuming $300 \mathrm{~kg} \mathrm{~N} \mathrm{ha}^{-1}$ and a soil depth of $60 \mathrm{~cm}$, increasing the harvest interval from 28 days to 35 days only marginally increased the yield from $7.3 \mathrm{t} \mathrm{ha}^{-1}$ to $7.6 \mathrm{t} \mathrm{ha}^{-1}$. There was also minimal effect of increasing the 
harvest interval from 28 days to 35 days at zero nitrogen application or an application of $150 \mathrm{~kg} \mathrm{~N} \mathrm{ha}{ }^{-1}$.

Table 7. Modelling the effect of rooting depth (RD) and harvest interval (HI) on the predicted total grass yield at Cambridge.

\begin{tabular}{|c|c|c|c|c|c|}
\hline \multirow{2}{*}{$\begin{array}{l}\text { Nitrogen } \\
\text { Application } \\
\left(\operatorname{kg~N~ha~}^{-1}\right)\end{array}$} & \multirow{2}{*}{$\begin{array}{c}\text { Observed Yield }\left(\mathrm{tha}^{-1}\right) \\
\text { HI }=28 \mathrm{~d} ; \\
\mathrm{RD}=60 \mathrm{~cm}\end{array}$} & \multicolumn{4}{|c|}{ Predicted Yield (t ha ${ }^{-1}$ ) } \\
\hline & & $\begin{aligned} H I & =28 \mathrm{~d} \\
\mathrm{RD} & =60 \mathrm{~cm}\end{aligned}$ & $\begin{aligned} H I & =28 \mathrm{~d} \\
\mathrm{RD} & =90 \mathrm{~cm}\end{aligned}$ & $\begin{aligned} H I & =35 \mathrm{~d} ; \\
\mathrm{RD} & =60 \mathrm{~cm}\end{aligned}$ & $\begin{array}{c}\mathrm{HI}=35 \\
\mathrm{RD}=90 \mathrm{~cm}\end{array}$ \\
\hline 0 & 2.7 & 1.0 & 1.0 & 0.9 & 0.9 \\
\hline 150 & 4.1 & 5.8 & 6.2 & 5.7 & 6.3 \\
\hline 300 & 7.2 & 7.3 & 8.4 & 7.6 & 8.4 \\
\hline 450 & 7.6 & 7.6 & 8.9 & 8.0 & 9.2 \\
\hline
\end{tabular}

HI: Harvest interval; RD: Rooting depth.

One other potential method to increase yields under dry conditions is to increase the organic matter content of the soil, thereby increasing the available water capacity. Across the 10 sites, there was a variation in the SOC/clay value from "degraded" to "very good" (Table 3). The five sites categorized as "very good" included Aberystwyth and Morpeth, which were previously permanent grassland sites. There is an argument that sites with a high SOC/clay value have a stable soil structure with well-developed macropores that creates favourable soil hydraulic properties in both the uppermost A horizon in the soil and the deeper Bt1 horizon [52,53].

\subsection{Soil and Nitrogen Uptake Efficiency}

An analysis of the nitrogen uptake efficiency (NUpE) indicated that across 10 sites (with the exception of Morpeth), the NUpE decreased from $0.76-0.89 \mathrm{~kg} \mathrm{~kg}^{-1}$ between 0 and $150 \mathrm{~kg} \mathrm{~N} \mathrm{ha}^{-1}$, to $0.41-0.46 \mathrm{~kg} \mathrm{~kg}^{-1}$ between 150 and $300 \mathrm{~kg} \mathrm{~N} \mathrm{ha}^{-1}$, and to $0.12-0.32 \mathrm{~kg} \mathrm{~kg}^{-1}$ between 300 and $450 \mathrm{~kg} \mathrm{~N} \mathrm{ha}^{-1}$ (Table 6). This reduction is in line with previous studies $[54,55]$ and is a result of the yields increasingly becoming constrained by factors other than $\mathrm{N}$ availability. The predicted NUpE at Morpeth was substantially lower. This is because, we assumed that at Morpeth, unlike the other sites, the soil mineral $\mathrm{N}$ available at the start of the season was $75 \mathrm{~kg}^{-1}$. Such an analysis demonstrates the potential importance of recent site history in determining $\mathrm{N}$ responses. At present the LINGRA-N-Plus model does not specifically account for increased leaching losses of $\mathrm{N}$ with high rainfall, instead assuming that only $70 \%$ of the applied $\mathrm{N}$ is available. The inclusion of such a leaching effect could be feature of future enhancements of the model, and it is possible that relative $\mathrm{N}$ uptake efficiencies may be overestimated under high rainfall. For LINGRA-N-Plus to become a more detailed model of $\mathrm{N}$ dynamics, $\mathrm{N}$ transformations such as denitrification, volatilization or urea hydrolysis could enhance its grass yield and $\mathrm{N}$ uptake/losses predictions.

The importance of the initial soil mineral $\mathrm{N}$ in determining the response of grass yields to $\mathrm{N}$ suggests that grassland fertilizer management would benefit from pre-season assessments of soil $\mathrm{N}$ status. Where the initial soil $\mathrm{N}$ content is high, lower than default fertilizer applications could reduce management costs and $\mathrm{N}$ losses to the environment. The appropriate $\mathrm{N}$ application may also depend on the soil texture, with the response to added $\mathrm{N}$ being generally greater in fine-textured than in medium-textured $[56,57]$. This may be related in turn to the available water capacity, or the observation that the decomposition of nitrogen from residues is slower in anaerobic rather than drier and well-aerated soils [58]. The availability of $\mathrm{N}$ to recently established grass may also depend on the type and quantity of residue from the previous crop. A previous crop residue that has a low $\mathrm{C}: \mathrm{N}$ ratio may be easily mineralized and provide more $\mathrm{N}$ in the soil in the following season [59]. 


\section{Conclusions}

The results show that LINGRA-N-Plus is a useful model for predicting the effects and interactions of different pedoclimatic conditions with management decisions, such as harvest intervals and $\mathrm{N}$ application rates, on both annual green leaf and total dry matter grass yields in England and Wales. Including a temperature and moisture dependent soil $\mathrm{N}$ mineralization routine and a modified algorithm to describe partitioning and harvest of stems, green and dead leaves, improved the predictions of the grass yields from an $\mathrm{N}$ fertilizer experiment across England over the original LINGRA-N model. The model highlighted the role of drought stress in limiting yields at sites with low rainfall, aggravated by shallow rooting depths, and low available water capacities. At such sites, dry matter yields could be increased by selecting varieties or species with a deeper rooting depth, removing soil-based limitations to rooting depth, adapting the harvest interval, and using management practices that enhance soil health, although these may also affect forage composition and quality. Modelled estimates of $\mathrm{N}$ uptake demonstrated a decline in efficiency per unit application with increasing application rates. Under zero-N application conditions, the (assumed) initial mineral $\mathrm{N}$ content in the soil becomes a major determinant of yield.

Author Contributions: Conceptualization, M.L.G., P.J.B., and G.M.R.; methodology, M.L.G., P.J.B., M.J.B., G.M.R., C.F.E.T., J.I., T.T.; software and validation: M.L.G., P.J.B. and G.M.R.; formal analysis, M.L.G.; writing — original draft preparation and visualization: M.L.G.; writing—review and editing, M.L.G., P.J.B., M.J.B., G.M.R., C.F.E.T., J.I., T.T. All authors have read and agreed to the published version of the manuscript.

Funding: This work was part of a grassland management translation project funded by the Natural Environment Research Council (NE/R017387/1) with the support of the Sustainable Agriculture Research and Innovation Club (SARIC). G.M. Richter and T. Takahashi acknowledge the support of Rothamsted Research's Institute Strategic Programme 'Soil to Nutrition' (BBS/E/C/000I0330) funded by the UK Biotechnology and Biological Sciences Research Council (BBSRC).

Institutional Review Board Statement: Not applicable.

Informed Consent Statement: Not applicable.

Data Availability Statement: Access LINGRA-N-Plus at https:/ / cord.cranfield.ac.uk/articles/code/ Data_underpinning_NERC_Research_Translation_Grassland_Management_project/11359613.

Acknowledgments: We are thankful to numerous farmers, consultants, students, and researchers who provided feedback on early versions of the LINGRA-N-Plus model. We are also thankful to Wilman et al. and Morisson et al. for reporting their results in a clear way that allowed calibration and validation of the models.

Conflicts of Interest: The authors declare no conflict of interest. 


\section{Appendix A}

Table A1. Harvesting regime for Wilman et al. [17].

\begin{tabular}{lcccccc}
\hline Harvest Interval (Weeks) & $\mathbf{3}$ & $\mathbf{4}$ & $\mathbf{5}$ & $\mathbf{6}$ & $\mathbf{8}$ & $\mathbf{1 0}$ \\
\hline Number of Harvests & $\mathbf{1 0}$ & $\mathbf{8}^{*}$ & $\mathbf{6}$ & $\mathbf{5}$ & $\mathbf{3}^{+}$ & $\mathbf{3}$ \\
\hline Date ${ }^{* *}$ & & & & & & \\
\hline 16 April & $1 \mathrm{st}$ & - & - & - & - & - \\
23 & - & 1 st & - & - & - & - \\
30 & - & - & 1 st & - & - & - \\
\hline 07 May & 2 nd & - & - & 1 st & - & - \\
21 & - & 2 nd & - & - & 1 st & - \\
28 & 3 rd & - & - & - & - & - \\
\hline 04 June & - & - & 2 nd & - & - & 1 st \\
18 & 4 th & 3 rd & - & 2 nd & - & - \\
\hline 09 July & 5 th & - & 3 rd & - & - & - \\
16 & - & 4 th & - & - & 2 nd & - \\
30 & 6 th & - & - & 3 rd & - & - \\
\hline 13 August & - & 5 th & 4 th & - & - & 2 nd \\
20 & 7 th & - & - & - & - & - \\
\hline 10 September & 8 th & 6 th & - & 4 th & 3 rd & - \\
17 & - & - & 5 th & - & - & - \\
\hline 01 October & 9 th & - & - & - & - & - \\
8 & - & 7 th & - & - & - & - \\
22 & 10 th & 8 th & 6 th & 5 th & 4 th & 3 rd \\
\hline${ }^{*}$ Final interval 2 weeks. ${ }^{+}$Final interval 6 weeks ${ }^{* *}$ N applications took place a day post cutting.
\end{tabular}

Table A2. Summary of selected part of the BBCH development stages of forage grasses (after Gustavsson 2011).

\begin{tabular}{ll}
\hline BBCH Stage & Description \\
\hline 0 & Germination \\
9 & Emergence of seedling at soil surface \\
$10-19$ & Leaf development \\
21 & Beginning of tillering; main shoot and one tiller detectable \\
30 & Beginning of stem elongation \\
50 & First spikelet of the inflorescence is just visible \\
60 & Beginning of flowering \\
65 & Full flowering; half of anthers mature \\
90 & Grain fully ripe \\
\hline
\end{tabular}


Table A3. Harvest regime for Morrison et al. [34].

\begin{tabular}{|c|c|c|c|c|c|c|}
\hline Site & & & $\mathrm{Cu}$ & ates & & \\
\hline Morpeth & 16 May & 13 Jun & $11 \mathrm{Jul}$ & 8 Aug & 5 Sep & 3 Oct \\
\hline High Mowthorpe & 14 May & 11 Jun & $9 \mathrm{Jul}$ & 6 Aug & 3 Sep & 1 Oct \\
\hline Leeds & 12 May & 9 Jun & $7 \mathrm{Jul}$ & 4 Aug & $1 \mathrm{Sep}$ & 29 Sep \\
\hline $\begin{array}{l}\text { Cambridge } \\
\text { Stratford upon Avon }\end{array}$ & 10 May & 7 Jun & $5 \mathrm{Jul}$ & 2 Aug & $30 \mathrm{Aug}$ & 27 Sep \\
\hline Newton Abbot & 6 May & 3 Jun & $1 \mathrm{Jul}$ & $29 \mathrm{Jul}$ & $26 \mathrm{Aug}$ & 23 Sep \\
\hline $\begin{array}{l}\text { Oxford } \\
\text { Hurley } \\
\text { Ashford } \\
\text { Winchester }\end{array}$ & 8 May & 5 Jun & $3 \mathrm{Jul}$ & $31 \mathrm{Jul}$ & $28 \mathrm{Aug}$ & 25 Sep \\
\hline
\end{tabular}

Table A4. Nitrogen applications for Morrisson et al. [34] experiment.

\begin{tabular}{|c|c|c|c|c|c|c|c|c|c|}
\hline \multicolumn{10}{|c|}{ Application Date * } \\
\hline Morpeth & $\begin{array}{l}\text { High } \\
\text { Mowthorpe }\end{array}$ & Leeds & Cambridge & $\begin{array}{l}\text { Newton } \\
\text { Abbot }\end{array}$ & Oxford & Hurley & Ashford & Stratford & Winchester \\
\hline $29 \mathrm{Mar}$ & $26 \mathrm{Mar}$ & $23 \mathrm{Mar}$ & $13 \mathrm{Mar}$ & 01 Mar & $27 \mathrm{Mar}$ & 19 Mar & $21 \mathrm{Mar}$ & $05 \mathrm{Apr}$ & $19 \mathrm{Mar}$ \\
\hline 17 May & 15 May & 13 May & 11 May & 07 May & 09 May & 09 May & 09 May & 11 May & 09 May \\
\hline 14 Jun & 12 Jun & 10 Jun & 08 Jun & 04 Jun & 06 Jun & 06 Jun & 06 Jun & 08 Jun & 06 Jun \\
\hline $12 \mathrm{Jul}$ & $10 \mathrm{Jul}$ & $08 \mathrm{Jul}$ & $06 \mathrm{Jul}$ & 02 Jul & $04 \mathrm{Jul}$ & $04 \mathrm{Jul}$ & $04 \mathrm{Jul}$ & $06 \mathrm{Jul}$ & $04 \mathrm{Jul}$ \\
\hline 09 Aug & 07 Aug & 05 Aug & 03 Aug & $30 \mathrm{Jul}$ & 01 Aug & 01 Aug & 01 Aug & 03 Aug & 01 Aug \\
\hline 06 Sep & 04 Sep & 02 Sep & 31 Aug & 27 Aug & 29 Aug & 29 Aug & 29 Aug & 31 Aug & 29 Aug \\
\hline
\end{tabular}

* Application date is the same for all $\mathrm{N}$ applications $\left(0,150,300\right.$ and $\left.450 \mathrm{~kg} \mathrm{~N} \mathrm{ha}^{-1}\right)$ and the amount of $\mathrm{N}$ is distributed equally per application day.

Table A5. Assumed soil moisture contents factors *.

\begin{tabular}{|c|c|c|c|}
\hline Site & $\mathrm{SM}_{\mathrm{FC}}(\mathrm{pF}=2.3)$ & $\mathrm{SM}_{\mathrm{PWP}}(\mathrm{pF}=4.2)$ & $\operatorname{SM}_{\mathrm{DRY}}(\mathrm{pF}=6)$ \\
\hline & $\left(\mathrm{mm}^{3} \mathrm{~mm}^{-3}\right)$ & $\left(\mathrm{mm}^{3} \mathrm{~mm}^{-3}\right)$ & $\left(\mathrm{mm}^{3} \mathrm{~mm}^{-3}\right)$ \\
\hline Aberystwyth & 0.32 & 0.19 & 0.03 \\
\hline Morpeth & 0.25 & 0.11 & 0.10 \\
\hline High Mowthorpe & 0.36 & 0.18 & 0.15 \\
\hline Leeds & 0.38 & 0.19 & 0.15 \\
\hline Cambridge & 0.17 & 0.13 & 0.10 \\
\hline Newton Abbot & 0.32 & 0.19 & 0.03 \\
\hline Oxford & 0.28 & 0.10 & 0.10 \\
\hline Hurley & 0.19 & 0.09 & 0.03 \\
\hline Ashford & 0.32 & 0.19 & 0.03 \\
\hline Stratford & 0.36 & 0.20 & 0.15 \\
\hline Winchester & 0.36 & 0.20 & 0.15 \\
\hline
\end{tabular}

* According to water release curve per soil texture. SM0: Soil moisture at saturation assumed $0.45 \mathrm{~mm}^{3} \mathrm{~mm}^{-3}$ $\mathrm{SM}_{\mathrm{FC}}$ : Soil moisture content at field capacity. $\mathrm{SM}_{\mathrm{PWP}}$ : Soil moisture content at wilting point. $\mathrm{SM}_{\mathrm{DRY}}$ : Soil moisture content at air dry. 
Table A6. Effect of harvest interval on the green leaf and total dry biomass yields ( $t \mathrm{ha}^{-1}$ ) at Aberystwyth as (a) observed by Wilman et al. [17] and (b) predicted by LINGRA-N-Plus.

\begin{tabular}{|c|c|c|c|c|c|c|c|c|c|c|c|}
\hline \multirow{2}{*}{\multicolumn{2}{|c|}{$\begin{array}{l}\text { Nitrogen } \\
\text { (kg N/ha) }\end{array}$}} & \multicolumn{10}{|c|}{ Harvest Interval (days) } \\
\hline & & \multirow[t]{2}{*}{2} & \multirow[t]{2}{*}{4} & \multirow[t]{2}{*}{7} & \multirow[t]{2}{*}{14} & \multirow[t]{2}{*}{21} & \multirow[t]{2}{*}{28} & \multirow[t]{2}{*}{35} & \multirow[t]{2}{*}{42} & \multirow[t]{2}{*}{56} & \multirow[t]{2}{*}{70} \\
\hline \multirow{3}{*}{$\begin{array}{l}\text { (a) } \\
0\end{array}$} & Observed & & & & & & & & & & \\
\hline & Green leaf & & & & & 3.41 & 3.91 & 4.23 & 4.06 & 3.64 & 3.29 \\
\hline & Total & & & & & 4.73 & 5.92 & 7.03 & 8.22 & 9.10 & 10.73 \\
\hline \multirow[t]{2}{*}{262} & Green leaf & & & & & 7.04 & 7.23 & 7.18 & 7.15 & 4.86 & 3.66 \\
\hline & Total & & & & & 9.36 & 10.88 & 12.45 & 13.93 & 14.19 & 14.57 \\
\hline \multirow[t]{2}{*}{525} & Green leaf & & & & & 8.2 & 8.59 & 8.49 & 7.19 & 5.01 & 3.65 \\
\hline & Total & & & & & 10.85 & 12.81 & 14.54 & 14.86 & 14.77 & 15.02 \\
\hline (b) & Predicted & & & & & & & & & & \\
\hline \multirow[t]{2}{*}{0} & Green leaf & 2.62 & 3.22 & 3.23 & 3.36 & 3.42 & 3.56 & 3.23 & 3.45 & 2.66 & 1.67 \\
\hline & Total & 2.98 & 3.69 & 3.75 & 4.07 & 4.66 & 5.59 & 5.71 & 7.10 & 7.21 & 6.48 \\
\hline \multirow{2}{*}{262} & Green leaf & 2.62 & 3.89 & 4.93 & 6.69 & 7.40 & 7.51 & 7.35 & 6.98 & 5.55 & 3.32 \\
\hline & Total & 2.98 & 4.43 & 5.60 & 8.04 & 10.20 & 11.37 & 12.40 & 13.15 & 13.54 & 13.72 \\
\hline \multirow[t]{2}{*}{525} & Green leaf & 2.62 & 3.89 & 4.93 & 6.69 & 7.48 & 7.94 & 7.92 & 7.43 & 5.68 & 3.32 \\
\hline & Total & 2.98 & 4.43 & 5.60 & 8.04 & 10.30 & 11.93 & 13.16 & 13.77 & 13.75 & 13.72 \\
\hline
\end{tabular}

Table A7. Effect of N applications on the total dry matter yields in 1972 and 1973 at 10 sites reported by Morrison et al. [34] as observed (Obs.) and predicted (Pred.) by the LINGRA-N-Plus.

\begin{tabular}{|c|c|c|c|c|c|c|c|c|c|c|c|c|}
\hline & $\begin{array}{l}\text { N app. } \\
\left(\operatorname{kg~ha}^{-1}\right)\end{array}$ & & Morpeth & $\begin{array}{l}\text { High } \\
\text { Mow- } \\
\text { thorpe }\end{array}$ & Leeds & Cambridge & $\begin{array}{c}\text { Newton } \\
\text { Abbot }\end{array}$ & Oxford & Hurley & Ashford & Stratford & Winchester \\
\hline \multirow{8}{*}{1972} & \multirow[b]{2}{*}{0} & Obs. & 7.1 & 1.6 & 0.4 & 1.4 & 3.8 & 2.6 & 1.3 & 0.7 & 1.4 & 2.1 \\
\hline & & Pred. & 5.5 & 1.5 & 1.3 & 1.0 & 1.7 & 2.1 & 1.5 & 1.3 & 1.6 & 1.5 \\
\hline & \multirow{2}{*}{150} & Obs. & 9.6 & 4.3 & 4.2 & 2.5 & 6.0 & 6.2 & 3.0 & 4.4 & 5.2 & 5.7 \\
\hline & & Pred. & 9.7 & 7.1 & 7.0 & 4.8 & 8.3 & 8.1 & 6.7 & 7.5 & 8.0 & 7.8 \\
\hline & \multirow{2}{*}{300} & Obs. & 13.2 & 6.4 & 9.5 & 4.3 & 8.7 & 10.2 & 5.8 & 7.8 & 8.7 & 8.6 \\
\hline & & Pred. & 11.9 & 9.9 & 9.8 & 5.7 & 12.8 & 11.5 & 8.9 & 10.8 & 12.2 & 11.9 \\
\hline & \multirow[b]{2}{*}{450} & Obs. & 14.3 & 6.4 & 11.7 & 4.9 & 9.9 & 15.0 & 7.9 & 10.4 & 9.6 & 10.2 \\
\hline & & Pred. & 12.1 & 10.7 & 10.6 & 5.9 & 14.8 & 12.6 & 9.7 & 11.9 & 13.9 & 13.5 \\
\hline \multirow{8}{*}{1973} & \multirow[b]{2}{*}{0} & Obs. & 8.0 & 3.5 & 0.8 & 2.7 & 2.8 & 2.9 & 1.6 & 0.5 & 1.3 & 2.2 \\
\hline & & Pred. & 5.9 & 1.4 & 1.4 & 1.0 & 1.6 & 2.3 & 1.5 & 1.2 & 1.6 & 1.7 \\
\hline & \multirow{2}{*}{150} & Obs. & 7.2 & 7.2 & 5.9 & 4.1 & 7.3 & 7.3 & 6.2 & 3.6 & 5.1 & 6.3 \\
\hline & & Pred. & 9.8 & 7.2 & 7.6 & 5.8 & 7.9 & 8.7 & 7.7 & 6.9 & 7.9 & 8.3 \\
\hline & \multirow[b]{2}{*}{300} & Obs. & 11.1 & 8.6 & 10.5 & 7.2 & 12.6 & 10.0 & 8.1 & 5.9 & 8.5 & 9.0 \\
\hline & & Pred. & 11.1 & 9.3 & 10.8 & 7.3 & 11.7 & 12.7 & 11.2 & 9.3 & 11.6 & 12.5 \\
\hline & \multirow{2}{*}{450} & Obs. & 10.2 & 9.9 & 12.1 & 7.6 & 11.1 & 10.8 & 11.2 & 7.4 & 9.9 & 10.1 \\
\hline & & Pred. & 11.1 & 9.6 & 11.7 & 7.6 & 12.9 & 14.2 & 12.1 & 10.2 & 12.8 & 14.3 \\
\hline
\end{tabular}

Table A8. Linear regression summary for LINGRA-N and LINGRA-N-Plus with Wilman et al. [17] (green leaf and dry matter yields; $\mathrm{t} \mathrm{ha}^{-1}$ ) per amount of applied $\mathrm{N}(\mathrm{kg} \mathrm{N} / \mathrm{ha})$.

\begin{tabular}{|c|c|c|c|c|c|c|}
\hline \multirow{3}{*}{$\begin{array}{l}\text { Descriptive } \\
\text { Statistics }\end{array}$} & \multicolumn{6}{|c|}{ N Application } \\
\hline & \multicolumn{2}{|c|}{$0 \mathrm{~kg} \mathrm{ha}^{-1}$} & \multicolumn{2}{|c|}{$262 \mathrm{~kg} \mathrm{ha}^{-1}$} & \multicolumn{2}{|c|}{$525 \mathrm{~kg} \mathrm{ha}^{-1}$} \\
\hline & LINGRA-N-Plus & LINGRA-N & LINGRA-N-Plus & LINGRA-N & LINGRA-N-Plus & LINGRA-N \\
\hline Constant & 0.80 & $1.81^{* * *}$ & 0.79 & 1.13 & $0.64 *$ & 1.59 \\
\hline Slope & $0.66^{* * *}$ & $0.48^{* * *}$ & $0.91^{* * *}$ & $0.81^{* * *}$ & $0.87^{* * *}$ & $0.71^{* * *}$ \\
\hline $\mathrm{R}^{2}$ & 0.821 & 0.754 & 0.981 & 0.741 & 0.991 & 0.618 \\
\hline RMSE & 1.57 & 1.81 & 0.54 & 1.95 & 0.85 & 2.78 \\
\hline EF & 0.57 & 0.43 & 0.97 & 0.70 & 0.95 & 0.48 \\
\hline
\end{tabular}


Table A9. Observed dry matter grass yields (DM) in 1972, as reported by Morrison et al. [34] and the associated nitrogen applications and levels of drought stress index.

\begin{tabular}{|c|c|c|c|c|c|}
\hline Site & $\mathrm{kg} \mathrm{N} \mathrm{ha}^{-1}$ & $\mathrm{DSI}^{+}$ & SOC/clay & DM Yield (t ha $\left.{ }^{-1}\right)$ & \\
\hline Oxford & 450 & Droughty & Degraded & 15.0 & $\mathrm{a}$ \\
\hline Morpeth & 450 & Non-droughty & Very good & 14.3 & $\mathrm{a}$ \\
\hline Morpeth & 300 & Non-droughty & Very good & 13.2 & $a b$ \\
\hline Leeds & 450 & Non-droughty & Moderate & 11.7 & $a b c$ \\
\hline Ashford & 450 & Droughty & Very good & 10.4 & bcd \\
\hline Oxford & 300 & Droughty & Degraded & 10.2 & bcd \\
\hline Winchester & 450 & Non-droughty & Degraded & 10.2 & bcd \\
\hline Newton Abbot & 450 & Non-droughty & Very good & 9.9 & bcde \\
\hline Morpeth & 150 & Non-droughty & Very good & 9.6 & bcdef \\
\hline Stratford & 450 & Non-droughty & Degraded & 9.6 & bcdef \\
\hline Leeds & 300 & Non-droughty & Moderate & 9.5 & cdef \\
\hline Newton Abbot & 300 & Non-droughty & Very good & 8.7 & cdefg \\
\hline Stratford & 300 & Non-droughty & Degraded & 8.7 & cdefg \\
\hline Winchester & 300 & Non-droughty & Degraded & 8.6 & cdefg \\
\hline Hurley & 450 & Droughty & Degraded & 7.9 & defgh \\
\hline Ashford & 300 & Droughty & Very good & 7.8 & defghi \\
\hline Morpeth & 0 & Non-droughty & Very good & 7.1 & defghij \\
\hline H.Mowthorpe & 300 & Droughty & Moderate & 6.4 & efghijk \\
\hline H.Mowthorpe & 450 & Droughty & Moderate & 6.4 & efghijk \\
\hline Oxford & 150 & Droughty & Degraded & 6.2 & fghijkl \\
\hline Newton Abbot & 150 & Non-droughty & Very good & 6.0 & fghijklm \\
\hline Hurley & 300 & Droughty & Degraded & 5.8 & ghijklm \\
\hline Winchester & 150 & Non-droughty & Degraded & 5.7 & ghijklmn \\
\hline Stratford & 150 & Non-droughty & Degraded & 5.2 & ghijklmno \\
\hline Cambridge & 450 & Droughty & Very good & 4.9 & hijklmnop \\
\hline Ashford & 150 & Droughty & Very good & 4.4 & hijklmnop \\
\hline Cambridge & 300 & Droughty & Very good & 4.3 & hijklmnopq \\
\hline H.Mowthorpe & 150 & Droughty & Moderate & 4.3 & hijklmnopq \\
\hline Leeds & 150 & Non-droughty & Moderate & 4.2 & ijklmnopq \\
\hline Newton Abbot & 0 & Non-droughty & Very good & 3.8 & jklmnopqr \\
\hline Hurley & 150 & Droughty & Degraded & 3.0 & klmnopqr \\
\hline Oxford & 0 & Droughty & Degraded & 2.6 & lmnopqr \\
\hline Cambridge & 150 & Droughty & Very good & 2.5 & mnopqr \\
\hline Winchester & 0 & Non-droughty & Degraded & 2.1 & nopqr \\
\hline H.Mowthorpe & 0 & Droughty & Moderate & 1.6 & opqr \\
\hline Cambridge & 0 & Droughty & Very good & 1.4 & pqr \\
\hline Stratford & 0 & Non-droughty & Degraded & 1.4 & pqr \\
\hline Hurley & 0 & Droughty & Degraded & 1.3 & pqr \\
\hline Ashford & 0 & Droughty & Very good & 0.7 & $\mathrm{qr}$ \\
\hline Leeds & 0 & Droughty & Moderate & 0.4 & $\mathrm{r}$ \\
\hline
\end{tabular}

${ }^{+}$DSI = PSMD-AWC: if values $>0$ then 'Dry', if values $<0$ then 'Wet'; Sites with the same letter are not significantly different. 
Table A10. Observed dry matter grass yields (DM) in 1973, as reported by Morrison et al. [34] and the associated nitrogen applications and levels of water stress index.

\begin{tabular}{|c|c|c|c|c|c|}
\hline Site & kg N ha ${ }^{-1}$ & $\mathrm{DSI}^{+}$ & SOC/clay & DM Yield (t ha-1) & \\
\hline Newton Abbot & 300 & Non-droughty & Very good & 12.6 & $\mathrm{a}$ \\
\hline Leeds & 450 & Non-droughty & Moderate & 12.1 & $a b$ \\
\hline Hurley & 450 & Droughty & Degraded & 11.2 & $a b c$ \\
\hline Morpeth & 300 & Non-droughty & Very good & 11.1 & abcd \\
\hline Newton Abbot & 450 & Non-droughty & Very good & 11.1 & abcd \\
\hline Oxford & 450 & Droughty & Degraded & 10.8 & abcde \\
\hline Leeds & 300 & Non-droughty & Moderate & 10.5 & abcdef \\
\hline Morpeth & 450 & Non-droughty & Very good & 10.2 & abcdef \\
\hline Winchester & 450 & Non-droughty & Degraded & 10.1 & abcdef \\
\hline Oxford & 300 & Droughty & Degraded & 10 & abcdef \\
\hline H.Mowthorpe & 450 & Non-droughty & Moderate & 9.9 & abcdef \\
\hline Stratford & 450 & Non-droughty & Degraded & 9.9 & abcdef \\
\hline Winchester & 300 & Non-droughty & Degraded & 9.0 & bcdefg \\
\hline H.Mowthorpe & 300 & Non-droughty & Moderate & 8.6 & bcdefgh \\
\hline Stratford & 300 & Non-droughty & Degraded & 8.5 & cdefgh \\
\hline Hurley & 300 & Droughty & Degraded & 8.1 & cdefgh \\
\hline Morpeth & 0 & Non-droughty & Very good & 8.0 & cdefgh \\
\hline Cambridge & 450 & Droughty & Very good & 7.6 & defghi \\
\hline Ashford & 450 & Droughty & Very good & 7.4 & efghi \\
\hline Newton Abbot & 150 & Non-droughty & Very good & 7.3 & efghi \\
\hline Oxford & 150 & Droughty & Degraded & 7.3 & efghi \\
\hline Cambridge & 300 & Droughty & Very good & 7.2 & fghi \\
\hline H.Mowthorpe & 150 & Non-droughty & Moderate & 7.2 & fghi \\
\hline Morpeth & 150 & Non-droughty & Very good & 7.2 & fghi \\
\hline Winchester & 150 & Non-droughty & Degraded & 6.3 & ghij \\
\hline Hurley & 150 & Droughty & Degraded & 6.2 & ghijk \\
\hline Ashford & 300 & Droughty & Very good & 5.9 & ghijk \\
\hline Leeds & 150 & Non-droughty & Moderate & 5.9 & ghijk \\
\hline Stratford & 150 & Non-droughty & Degraded & 5.1 & hijkl \\
\hline Cambridge & 150 & Droughty & Very good & 4.1 & ijklm \\
\hline Ashford & 150 & Droughty & Very good & 3.6 & jklmn \\
\hline H.Mowthorpe & 0 & Non-droughty & Moderate & 3.5 & jklmn \\
\hline Oxford & 0 & Droughty & Degraded & 2.9 & jklmn \\
\hline Newton Abbot & 0 & Non-droughty & Very good & 2.8 & jklmn \\
\hline Cambridge & 0 & Droughty & Very good & 2.7 & klmn \\
\hline Winchester & 0 & Non-droughty & Degraded & 2.2 & $\operatorname{lmn}$ \\
\hline Hurley & 0 & Droughty & Degraded & 1.6 & $\operatorname{lm} n$ \\
\hline Stratford & 0 & Non-droughty & Degraded & 1.3 & $\mathrm{mn}$ \\
\hline Leeds & 0 & Non-droughty & Moderate & 0.8 & $\mathrm{mn}$ \\
\hline Ashford & 0 & Droughty & Very good & 0.5 & $\mathrm{n}$ \\
\hline
\end{tabular}

${ }^{+}$DSI = PSMD-AWC: if values $>0$ then 'Dry', if values $<0$ then 'Wet'; Sites with the same letter are not significantly different. 
Table A11. Nitrogen uptake and incremental N uptake efficiency for the remaining sites and four N applications in 1973.

\begin{tabular}{lllllll}
\hline & $\begin{array}{l}\text { N Application } \\
\left(\mathbf{k g ~ N ~ h a}^{-1}\right)\end{array}$ & Leeds & Newton Abbot & Ashford & Stratford & Winchester \\
\hline $\begin{array}{l}\text { N uptake } \\
\left(\mathrm{kg} \mathrm{N} \mathrm{ha}^{-1}\right)\end{array}$ & 0 & 21 & 24 & 19 & 25 & 24 \\
& 150 & 125 & 128 & 120 & 129 & 128 \\
& 300 & 230 & 233 & 224 & 234 & 233 \\
& 450 & 319 & 338 & 287 & 338 & 338 \\
\hline Incremental N & 0 to 150 & 0.83 & 0.81 & 0.84 & 0.81 & 0.81 \\
uptake efficiency & 150 to 300 & 0.46 & 0.45 & 0.46 & 0.45 & 0.45 \\
$\left(\mathrm{~kg} \mathrm{~N}(\mathrm{~kg} \mathrm{~N})^{-1}\right)$ & 300 to 450 & 0.28 & 0.31 & 0.22 & 0.31 & 0.31 \\
\hline
\end{tabular}

Table A12. Comparing the effect of water-stress versus non-limiting water conditions on the site's total dry matter (DM) yields.

\begin{tabular}{llll}
\hline Site & Year & DM Yield Decrease & \\
\hline Cambridge & 1972 & 4.05 & $\mathrm{a}$ \\
Cambridge & 1973 & 3.30 & $\mathrm{ab}$ \\
Hurley & 1972 & 2.27 & $\mathrm{bc}$ \\
Ashford & 1973 & 1.50 & $\mathrm{~cd}$ \\
Ashford & 1972 & 0.58 & $\mathrm{de}$ \\
Hurley & 1973 & 0.25 & $\mathrm{de}$ \\
Oxford & 1972 & 0.20 & $\mathrm{de}$ \\
H.Mowthorpe & 1972 & 0.20 & $\mathrm{de}$ \\
Oxford & 1973 & 0.02 & $\mathrm{de}$ \\
Winchester & 1973 & 0.02 & $\mathrm{de}$ \\
Stratford & 1972 & 0.02 & $\mathrm{de}$ \\
Stratford & 1973 & 0.02 & $\mathrm{de}$ \\
Morpeth & 1973 & 0.02 & $\mathrm{de}$ \\
H.Mowthorpe & 1973 & 0.00 & $\mathrm{de}$ \\
Leeds & 1972 & 0.00 & $\mathrm{de}$ \\
Leeds & 1973 & 0.00 & $\mathrm{de}$ \\
Morpeth & 1972 & 0.00 & $\mathrm{de}$ \\
Newton Abbot & 1972 & 0.00 & $\mathrm{de}$ \\
Winchester & 1972 & 0.00 & $\mathrm{de}$ \\
Aberystwyth & 1973 & 0.00 & $\mathrm{e}$ \\
Newton Abbot & 1973 & 0.00 & $\mathrm{e}$ \\
\hline Sites with the same letter are & notignificantly different & &
\end{tabular}

\section{References}

1. Havlík, P.; Valin, H.; Herrero, M.; Obersteiner, M.; Schmid, E.; Rufino, M.C.; Mosnier, A.; Thornton, P.K.; Böttcher, H.; Conant, R.T.; et al. Climate change mitigation through livestock system transitions. Proc. Natl. Acad. Sci. USA 2014, 111, 3709-3714. [CrossRef]

2. Lugato, E.; Panagos, P.; Bampa, F.; Jones, A.; Montanarella, L. A new baseline of organic carbon stock in European agricultural soils using a modelling approach. Glob. Chang. Biol. 2013, 20, 313-326. [CrossRef] [PubMed]

3. Huyghe, C.; De Vliegher, A.; van Gils, B.; Peeters, A. Grasslands and Herbivore Production in Europe and Effects of Common Policies; Editions Quae: Versailles, France, 2014.

4. Soussana, J.; Tallec, T.; Blanfort, V. Mitigating the greenhouse gas balance of ruminant production systems through carbon sequestration in grasslands. Animal 2010, 4, 334-350. [CrossRef] [PubMed]

5. Scollan, N.D.; Greenwood, P.L.; Newbold, C.J.; Ruiz, D.R.Y.; Shingfield, K.J.; Wallace, R.J.; Hocquette, J.-F. Future research priorities for animal production in a changing world. Anim. Prod. Sci. 2011, 51, 1-5. [CrossRef]

6. Smith, P. Do grasslands act as a perpetual sink for carbon? Glob. Chang. Biol. 2014, 20, 2708-2711. [CrossRef] [PubMed]

7. Lüscher, A.; Fuhrer, J.; Newton, P.C.D. Global atmospheric change and its effect on managed grassland systems. In Grassland-A Global Resource; McGilloway, D.A., Ed.; Academic Publishers: Wageningen, The Netherlands, 2005; pp. 251-264. 
8. Buttler, A.; Mariotte, P.; Meisser, M.; Guillaume, T.; Signarbieux, C.; Vitra, A.; Preux, S.; Mercier, G.; Quezada, J.; Bragazza, L.; et al. Drought-induced decline of productivity in the dominant grassland species Lolium perenne L. depends on soil type and prevailing climatic conditions. Soil Biol. Biochem. 2019, 132, 47-57. [CrossRef]

9. Perera, R.S.; Cullen, B.R.; Eckard, R.J. Using Leaf Temperature to Improve Simulation of Heat and Drought Stresses in a Biophysical Model. Plants 2019, 9, 8. [CrossRef]

10. Rounsevell, M.; Brignall, A.; Siddons, P. Potential climate change effects on the distribution of agricultural grassland in England and Wales. Soil Use Manag. 1996, 12, 44-51. [CrossRef]

11. Riedo, M.; Gyalistras, D.; Fischlin, A.; Fuhrer, J. Using an ecosystem model linked to GCM-derived local weather scenarios to analyse effects of climate change and elevated $\mathrm{CO}_{2}$ on dry matter production and partitioning, and water use in temperate managed grasslands. Glob. Chang. Biol. 1999, 5, 213-223. [CrossRef]

12. Morales, P.; Hickler, T.; Rowell, D.P.; Smith, B.; Sykes, M.T. Changes in European ecosystem productivity and carbon balance driven by regional climate model output. Glob. Chang. Biol. 2006, 13, 108-122. [CrossRef]

13. Geris, J.; Tetzlaff, D.; McDonnell, J.; Soulsby, C. The relative role of soil type and tree cover on water storage and transmission in northern headwater catchments. Hydrol. Process. 2014, 29, 1844-1860. [CrossRef]

14. Garwood, E.A.; Williams, T.E. Soil water use and growth of a grass sward. J. Agric. Sci. 1967, 68, 281-292. [CrossRef]

15. Lin, H. Earth's Critical Zone and hydropedology: Concepts, characteristics, and advances. Hydrol. Earth Syst. Sci. 2010, 14, 25-45. [CrossRef]

16. Binnie, R.C.; Harrington, F.J. The effect of cutting height and cutting frequency on the productivity of an Italian ryegrass sward. Grass Forage Sci. 1972, 27, 177-182. [CrossRef]

17. Wilman, D.; Droushiotis, D.; Koocheki, A.; Lwoga, A.B.; Shim, J.S. The effect of interval between harvests and nitrogen application on the digestibility and digestible yield and nitrogen content and yield of four ryegrass varieties in the first harvest year. J. Agric. Sci. 1976, 86, 393-399. [CrossRef]

18. Herrmann, A.; Kelm, M.; Kornher, A.; Taube, F. Performance of grassland under different cutting regimes as affected by sward composition, nitrogen input, soil conditions and weather-A simulation study. Eur. J. Agron. 2005, 22, 141-158. [CrossRef]

19. Crider, F.J. Root-Growth Stoppage Resulting from Defoliation of Grass; USDA Technical Bulletin No. 1102; USDA: Washington, WA, USA, 1955.

20. Davidson, J.L.; Milthorpe, F.L. Carbohydrate reserves in the regrowth of cocksfoot (Dactylis glomerate L.). J. Br. Orassld Soc. 1965, 20, 15-18. [CrossRef]

21. Wilman, D.; Mohamed, A.A. Response to nitrogen application and interval between harvests in five grasses? Leaf development. Nutr. Cycl. Agroecosyst. 1981, 2, 3-20. [CrossRef]

22. Lamsal, A.; Welch, S.; Jones, J.; Boote, K.; Asebedo, A.; Crain, J.; Wang, X.; Boyer, W.; Giri, A.; Frink, E.; et al. Efficient crop model parameter estimation and site characterization using large breeding trial data sets. Agric. Syst. 2017, 157, 170-184. [CrossRef]

23. Jones, J.W.; Antle, J.M.; Basso, B.; Boote, K.J.; Conant, R.T.; Foster, I.; Godfray, H.C.J.; Herrero, M.; Howitt, R.E.; Janssen, S.; et al. Toward a new generation of agricultural system data, models, and knowledge products: State of agricultural systems science. Agric. Syst. 2017, 155, 269-288. [CrossRef]

24. Qi, A.; Murray, P.J.; Richter, G.M. Modelling productivity and resource use efficiency for grassland ecosystems in the UK. Eur. J. Agron. 2017, 89, 148-158. [CrossRef]

25. Basso, B.; Dumont, B.; Maestrini, B.; Shcherbak, I.; Robertson, G.P.; Porter, J.R.; Smith, P.; Paustian, K.; Grace, P.R.; Asseng, S.; et al. Soil Organic Carbon and Nitrogen Feedbacks on Crop Yields under Climate Change. Agric. Environ. Lett. 2018, 3 , 180026. [CrossRef]

26. Schapendonk, A.; Stol, W.; Van Kraalingen, D.; Bouman, B. LINGRA, a sink/source model to simulate grassland productivity in Europe. Eur. J. Agron. 1998, 9, 87-100. [CrossRef]

27. Rodriguez, D.; Van Oijen, M.; Schapendonk, A.H.M.C. LINGRA-CC: A sink-source model to simulate the impact of climate change and management on grassland productivity. New Phytol. 1999, 144, 359-368. [CrossRef]

28. Wolf, J. Users Guide for LINGRA-N: Simple Generic Model for Simulation of Crop Growth under Potential, Water Limited and Nitrogen Limited Conditions. 2012. Available online: https:/ / models.pps.wur.nl/lingra-n-grassland-model-potential-waterlimited-and-n-limited-conditions-fortran (accessed on 15 January 2019).

29. Burgess, P.J.; Giannitsopoulos, M.L.; Richter, G.M.; Topp, C.F.E.; Bell, M.; Takahashi, T.; Ingram, J. Modelling Grass Growth with LINGRA-N-Plus: Teaching Guide; Cranfield University: Oxfordshire, UK, 2020; 23p. Available online: https:/ / cord.cranfield.ac.uk/articles/software/Data_underpinning_NERC_Research_Translation_Grassland_Management_ project $/ 11359613$ ?file=24173714 (accessed on 14 September 2020).

30. Kersebaum, K. Application of a simple management model to simulate water and nitrogen dynamics. Ecol. Model. 1995, 81, 145-156. [CrossRef]

31. Addiscott, T.M.; Whitmore, A.P. Computer simulation of changes in soil mineral nitrogen and crop nitrogen during autumn, winter and spring. J. Agric. Sci. 1987, 109, 141-157. [CrossRef]

32. Stanford, G.; Smith, S.J. Nitrogen mineralization potentials of soils. Soil Sci. Am. J. Proc. 1972, 36, 465-472. [CrossRef]

33. Abdelmagid, H.M. Factors Affecting Nitrogen Mineralization and Nitrate Reduction in Soils. Master's Thesis, Iowa State University, Ames, IA, USA, 1980. Retrospective Theses and Dissertations. Available online: https://lib.dr.iastate.edu/rtd/6820 (accessed on 23 November 2020). 
34. Morrison, J.; Jackson, M.V.; Sparrow, P.E. The Response of Perennial Ryegrass to Fertilizer Nitrogen in Relation to Climate and Soil. Report of the joint ADAS/GRI Grassland Manuring Trial-GM 20; Technical Report No 27; February 1980; Grassland Research Institute, ADAS and Rothamsted Experimental Station: Harpenden, UK, 1980. Available online: https:/ / www.worldcat.org/title/response-of-perennial-ryegrass-to-fertilizer-nitrogen-in-relation-to-climate-and-soil-reportof-the-joint-adasgri-grassland-manuring-trial-gm-20/oclc/838477580 (accessed on 20 March 2019).

35. Nüske, A.; Richter, J. N-mineralization in Löss-Parabrownearthes: Incubation experiments. Plant Soil 1981, 59, 237-247. [CrossRef]

36. Richter, G.; Hoffmann, A.; Nieder, R.; Richter, J. Nitrogen mineralization in loamy arable soils after increasing the ploughing depth and ploughing grasslands. Soil Use Manag. 1989, 5, 169-173. [CrossRef]

37. Gustavsson, A. A developmental scale for perennial forage grasses based on the decimal code framework. Grass Forage Sci. 2011, 66, 93-108. [CrossRef]

38. Brown, I.; Poggio, L.; Gimona, A.; Castellazzi, M. Climate change, drought risk and land capability for agriculture: Implications for land use in Scotland. Reg. Environ. Chang. 2011, 11, 503-518. [CrossRef]

39. Perryman, S.A.M.; Castells-Brooke, N.I.D.; Glendining, M.J.; Goulding, K.W.T.; Hawkesford, M.J.; Macdonald, A.J.; Ostler, R.J.; Poulton, P.R.; Rawlings, C.J.; Scott, T.; et al. The electronic Rothamsted Archive (e-RA), an online resource for data from the Rothamsted long-term experiments. Sci. Data 2018, 5, 180072. [CrossRef]

40. Harrison, A.F.; Howard, D.M.; Lawson, G.J. UK Soils: Their Phosphorus Sorption Capacity and Potential for P Removal from Sewage Effluents in Emergent Hydrophyte Treatment Systems; NERC/Institute of Terrestrial Ecology: London, UK, 1988; 179p, Available online: http:/ / nora.nerc.ac.uk/id/eprint/6204/1/HarrisonT01014a5N006204CR.pdf (accessed on 16 March 2020).

41. Cranfield University. The Soils Guide; Cranfield University: Cranfield, UK, 2020. Available online: www.landis.org.uk (accessed on 8 November 2020).

42. R Core Team. R: A Language and Environment for Statistical Computing; R Foundation for Statistical Computing: Vienna, Austria, 2018; Available online: https: / / www.R-project.org (accessed on 14 January 2019).

43. Smith, P.; Smith, J.; Powlson, D.; McGill, W.; Arah, J.; Chertov, O.; Coleman, K.; Franko, U.; Frolking, S.; Jenkinson, D.; et al. A comparison of the performance of nine soil organic matter models using datasets from seven long-term experiments. Geoderma 1997, 81, 153-225. [CrossRef]

44. Johannes, A.; Matter, A.; Schulin, R.; Weisskopf, P.; Baveye, P.C.; Boivin, P. Optimal organic carbon values for soil structure quality of arable soils. Does clay content matter? Geoderma 2017, 302, 14-21. [CrossRef]

45. Prout, J.M.; Shepherd, K.D.; McGrath, S.P.; Kirk, G.J.D.; Haefele, S.M. What is a good level of soil organic matter? An index based on organic carbon to clay ratio. Eur. J. Soil Sci. 2020,1-11. [CrossRef]

46. Topp, C.F.E.; Doyle, C.J. Modelling the comparative productivity and profitability of grass and legume systems of silage production in northern Europe. Grass Forage Sci. 2004, 59, 274-292. [CrossRef]

47. National Soil Resources Institute. Impacts of Climate Change on Soil Functions (Project code SP0538); Report for DEFRA; Department for Environment, Food and Rural Affairs: London, UK, 2005.

48. Abassi, M.K.; Kazmi, M.; Hussan, F.U. Nitrogen Use Efficiency and Herbage Production of an Established Grass Sward in Relation to Moisture and Nitrogen Fertilization. J. Plant Nutr. 2005, 28, 1693-1708. [CrossRef]

49. Waraich, E.A.; Ahmad, R.; Ashraf, M.Y. Role of mineral nutrition in alleviation of drought stress in plants. Aust. J. Crop Sci. 2011, $5,764-777$.

50. Lowe, J.; Bernie, D.; Bett, P.; Bricheno, L.; Brown, S.; Calvert, D.; Clark, R.; Eagle, K.; Edwards, T.; Fosser, G.; et al. UKCP18 Science Overview Report, November 2018 (Updated March 2019). Available online: https:/ / www.metoffice.gov.uk/pub/data/weather/ uk/ukcp18/science-reports/UKCP18-Land-report.pdf (accessed on 14 November 2020).

51. Armstrong, A.; Castle, D. Potential impacts of climate change on patterns of production and the role of drainage in grassland. Grass Forage Sci. 1992, 47, 50-61. [CrossRef]

52. Gregory, A.S.; Webster, C.P.; Watts, C.W.; Whalley, W.R.; MacLeod, C.J.A.; Joynes, A.; Papadopoulos, A.; Haygarth, P.M.; Binley, A.; Humphreys, M.W.; et al. Soil Management and Grass Species Effects on the Hydraulic Properties of Shrinking Soils. Soil Sci. Soc. Am. J. 2010, 74, 753-761. [CrossRef]

53. Kodešová, R.; Jirků, V.; Kodeš, V.; Mühlhanselová, M.; Nikodem, A.; Žigová, A. Soil structure and soil hydraulic properties of Haplic Luvisol used as arable land and grassland. Soil Tillage Res. 2011, 111, 154-161. [CrossRef]

54. Lassaletta, L.; Billen, G.; Grizzetti, B.; Anglade, J.; Garnier, J. 50 Year trends in nitrogen use efficiency of world cropping systems: The relationship between yield and nitrogen input to cropland. Environ. Res. Lett. 2014, 9, 105011. [CrossRef]

55. Swaney, D.P.; Howarth, R.W.; Hong, B. Nitrogen use efficiency and crop production: Patterns of regional variation in the United States, 1987-2012. Sci. Total Environ. 2018, 635, 498-511. [CrossRef] [PubMed]

56. Ashman, M.R.; Geeta, P. Essential Soil Science. A Clear and Concise Introduction to Soil Science; Blackwell Science: Oxford, UK, 2002.

57. Tremblay, N.; Bouroubi, Y.M.; Bélec, C.; Mullen, R.W.; Kitchen, N.R.; Thomason, W.E.; Ebelhar, S.; Mengel, D.B.; Raun, W.R.; Francis, D.D.; et al. Corn Response to Nitrogen is Influenced by Soil Texture and Weather. Agron. J. 2012, 104, 1658-1671. [CrossRef]

58. Hassink, J. Effects of soil texture and grassland management on soil organic $\mathrm{C}$ and $\mathrm{N}$ and rates of $\mathrm{C}$ and $\mathrm{N}$ mineralization. Soil Biol. Biochem. 1994, 26, 1221-1231. [CrossRef]

59. Withers, P.; Sylvester-Bradley, R. Nitrogen fertilizer requirements of cereals following grass. Soil Use Manag. 2006, 15, 221-229. [CrossRef] 